\title{
Prospects of Using Hydrocarbon Deposits from the Autochthonous Miocene Formation (Eastern Carpathian Foredeep, Poland) for Geothermal Purposes
}

\author{
Anna Chmielowska *D, Anna Sowiżdżał (D) and Barbara Tomaszewska (D) \\ Department of Fossil Fuels, Faculty of Geology, Geophysics and Environmental Protection, AGH University of \\ Science and Technology, Mickiewicza 30 Avenue, 30-059 Kraków, Poland; ansow@agh.edu.pl (A.S.); \\ bts@agh.edu.pl (B.T.) \\ * Correspondence: adrabik@agh.edu.pl
}

Citation: Chmielowska, A.;

Sowiżdżał, A.; Tomaszewska, B.

Prospects of Using Hydrocarbon

Deposits from the Autochthonous

Miocene Formation (Eastern

Carpathian Foredeep, Poland) for

Geothermal Purposes. Energies 2021,

14, 3102. https://doi.org/10.3390/

en14113102

Academic Editor: Rao Martand Singh

Received: 23 April 2021

Accepted: 24 May 2021

Published: 26 May 2021

Publisher's Note: MDPI stays neutral with regard to jurisdictional claims in published maps and institutional affiliations.

Copyright: (c) 2021 by the authors. Licensee MDPI, Basel, Switzerland. This article is an open access article distributed under the terms and conditions of the Creative Commons Attribution (CC BY) license (https:/ / creativecommons.org/licenses/by/ $4.0 /)$.
Abstract: There are many oil and gas fields around the world where the vast number of wells have been abandoned or suspended, mainly due to the depletion of reserves. Those abandoned oil and gas wells (AOGWs) are often located in areas with a prospective geothermal potential and might be retrofitted to a geothermal system without high-cost drilling. In Poland, there are thousands of wells, either operating, abandoned or negative, that might be used for different geothermal applications. Thus, the aim of this paper is not only to review geothermal and petroleum facts about the Eastern Carpathian Foredeep, but also to find out the areas, geological structures or just AOGWs, which are the most prospective in case of geothermal utilization. Due to the inseparability of geological settings with both oil and gas, as well as geothermal conditionings, firstly, the geological background of the analyzed region was performed, considering mainly the autochthonous Miocene formation. Then, geothermal and petroleum detailed characteristics were made. In the case of geothermal parameters, such as formation's thickness, temperatures, water-bearing horizons, wells' capacities, mineralization and others were extensively examined. Considering oil and gas settings, insights into reservoir rocks, hydrocarbon traps and migration paths issues were created. Then, for evaluating geothermal parameters for specific hydrocarbon reservoirs, their depths were established based on publicly available wells data. Thereafter, the average temperatures for selected reservoirs were set. As the effect, it turned out that most of the deposits have average temperatures of $40 / 50{ }^{\circ} \mathrm{C}$, nonetheless, there are a few characterized by higher (even around $80^{\circ} \mathrm{C}$ ) temperatures at reasonable depths.

Keywords: earth sciences; geothermal energy; petroleum field; eastern carpathian foredeep; Poland

\section{Introduction}

Geothermal energy is endowed with considerable energetic potential, either due to the continuous availability, independence from weather conditions and minor impact on the natural environment [1-5]. Besides, because of the constant heat flow from the Earth's interior, geothermal resources are almost inexhaustible and can be considered as an unlimited supply of energy for billions of years [1,3]. They can be harnessed for thermal energy (mainly district heating) and the generation of electricity; therefore, they are characterized by a wide range of possible applications [6-9]. Geothermal resources constitute the regional wealth that might be an excellent alternative and/or complement to fossil fuels. Thus, the use of geothermal energy can lead to a reduction in the phenomenon of energy poverty $[10,11]$, while contributing to increasing the country's energy independence [12]. Apart from shallow geothermic (i.e., heat pump technology), the utilization of geothermal energy is possible due to the deep boreholes, either brand-new ones dedicated to geothermal extraction, or old, petroleum wells readapted for geothermal purposes [13]. Drilling a new geothermal well requires not only an extensive designing phase and legal compliance [14], but also entails high investment costs [15]. Therefore, the issue of ren- 
dering old abandoned petroleum wells for geothermal is a highly desirable solution all around the globe. Additionally, changing legal conditions and greater care for the natural environment led to the search for new, effective solutions in case of adaptation of existing petroleum wells.

Due to the depletion of oil and gas resources, the vast number of boreholes are being abandoned and/or liquidated. Thus far, the number of abandoned petroleum wells, all over the world, has reached 30 million [15-17]. Additionally, many of them are located in areas characterized by more or less favorable geothermal parameters (temperature, pressure, outflow, etc.) that enable and justify them to be used again [18]. The possibility of transforming those petroleum wells into geothermal ones may have a result in limiting investment costs (drilling phase) [15,19], increasing the use of geothermal resources, and reducing the threat to the natural environment [20]. Therefore, the re-development of old oil and gas wells to acquire geothermal energy is a firmly desirable concept, and simultaneously the outstanding subject area of a significant number of ongoing research studies worldwide.

Within world scientific considerations, the re-use of wells after the production of hydrocarbons or negative exploratory and research wells (all referred to as abandoned oil and gas wells, abbr. AOGWs) to exploit geothermal energy resources have been broadly discussed $[15,17,21,22]$. Concepts focused on electricity production [21,23-25], the space heating sector $[19,22,26]$, and other possible technological applications, such as the desalination process $[17,27,28]$ or heat storage [29], have been presented in journals of globally. Scientists have considered various implementations of petroleum wells in either open- or closed-loop geothermal systems. In many countries, including Albania, China, Croatia, Israel, New Zealand, Poland (Mszczonów IG-1 well; [30-32]), Hungary and the USA, projects considering open-loop systems have been already realized or are currently being implemented [22]. An innovative approach was presented by Cheng et al. [33] or Caulk and Tomac [15], who proposed to re-use old/abandoned petroleum wells in combination with Enhanced Geothermal Systems (EGS) technology. Despite the tremendous potential of geothermal energy existing within oil and gas fields, the encountered brines' temperatures are not always high enough to meet the requirements for direct utilization. By default of sufficient temperatures, other solutions are being sought. One of the currently conducted researches concerns the assessment of adaptability of AOGWs for deep borehole heat exchanger (abbr. DBHE) technology [34,35]. Primarily, the co-axial DBHEs working on AOGWs are discussed among the scientific society [19,21,23,33,36]; and simultaneously, the U-tube type of DBHEs is considered less frequently [22].

Poland has a long-established history of petroleum, dating back to the Middle Ages (the 16th century), however, the first commercially organized modern petroleum well was drilled in 1854 in Bóbrka Village (i.e., Carpathian Petroleum Province). Nowadays, five petroleum provinces can be distinguished: the Carpathians, Wielkopolska, Lublin, Pomerania and Gdańsk, as well as Lower Paleozoic Shale Gas and Oil Belt [37]. Thus, summarily, more than 8000 boreholes deeper than $1000 \mathrm{~m}$ and more than 150,000 wells up to $500 \mathrm{~m}$ deep exist, either operating, abandoned (or liquidated) or negatively exploratory [37]. In turn, geothermal researchers in Poland have been continuously conducted since 1980 [38-44], and ten years later, the utilization of geothermal resources began [45]. There are mainly hydrogeothermal resources located at various depths, and thereby within different stratigraphic layers within geothermal provinces of the Polish Lowlands, the Carpathians, the Carpathian Foredeep and the Sudetes. Geothermal energy is used in six geothermal district heating plants and several local district heating networks, as well as in a few recreational and balneological centers $[45,46]$. Generally, the utilization of geothermal energy is based primarily on new geothermal-dedicated wells, except for the Mszczonów town, where the reconstructed single-well (Mszczonów IG-1 borehole) has been operating for the geoDistrict Heating Plant for around 20 years [13,30,31], as well as the Poreba Wielka village, were revitalized well (Poręba Wielka IG-1 borehole) has been used for recreational/healing purposes [13]. 
The vast majority of oil and gas wells are located within two petroleum provinces, namely, the Carpathians and the Greater Poland which correspond with relevant geothermal provinces: the Carpathians together with the Carpathian Foredeep, as well as the Polish Lowlands, respectively. Hence, the geothermal analysis undertaken within this paper focuses on the part of the Carpathian Petroleum Province, relevant to the area of the Carpathian Foredeep. The main purpose of this analysis is to determine the areas within the autochthonous Miocene formation of the Polish part of the Carpathian Foredeep, which, being oil and gas areas, are also characterized by relevant geothermal parameters enabling potential energetic application in the future. The indication of natural gas fields characterized by favorable geothermal parameters will enable the following analysis on particular hydrocarbon wells for possible re-adaptation for geothermal purposes as a local heat and/or energy supply. This work is an original and the first collective study of this type of geothermal condition within the hydrocarbon deposits in the eastern part of the Polish Carpathian Foredeep. It is a collection of valuable information on the main geothermal parameters, among which the estimated values of the temperatures expected to be obtained within specific deposits are of particular importance. The presented work could be considered as a basis for further research on the possibilities of managing geothermal energy accumulated within specific hydrocarbon structures, along with an assessment of the possibility of using the existing production infrastructure.

This review article contains general administrative, geological and geographical backgrounds for the eastern part of the Carpathian Foredeep-the analyzed area. Those are followed by a comprehensive geothermal analysis of the autochthonous Miocene formation, as well as detailed characteristics of oil and gas fields. The subsequent geothermal parameters were discussed throughout the paper: (1) Miocene thickness, (2) thermic parameters, (3) reservoir temperatures, (4) water-bearing horizons, (5) well's capacities, (6) total dissolved solids, abbr. TDS, (7) other reservoir parameters-hydraulic conductivity, effective porosity, permeability and shale volume. Petroleum characteristics of the analyzed area, besides the overall description of oil and gas fields, also contain information on reservoir rocks, hydrocarbon traps and gas migration paths. An important element is an attempt to estimate the temperatures in the selected hydrocarbon deposits depending on their location and the average depth of deposition. As a result, several deposits that stand out among the considered ones with a higher estimated temperature were indicated. Several of them have been discussed in detail.

\section{Materials and Methods}

This review article is an attempt to integrate publicly available data from the oil and gas industry, with the results of geothermal studies conducted so far in the Polish part of the Carpathian Foredeep. To identify the most prospective area(s) within the Autochthonous Miocene for geothermal energy utilization, the analysis of the current state of knowledge in the field of geology, oil and gas and geothermal issues has been carried out, relevant to the determined region. The including references were selected as a result of the integration of search methods by providing key authors for the field, research area and location of the analysis, and by variable sequences of keywords. Commonly known databases of scientific articles, as well as scientific and general internet search engines, were used. Subsequent publications were added to the list based on the attached bibliographies of previously positively verified publications.

The paper presents the basic geographical [47] and geological characteristics of the area, which determines the occurrence of mainly natural gas [48] and crude oil deposits, as well as specific hydro-geothermal conditions. Discussing the geological settings (i.e., [49-51]) of the region, the autochthonous Miocene has been of the authors' highest concern. The work tending towards the assessment of the region's geothermal potential has been carried out based on the Geothermal Atlas of Carpathian Foredeep [50] implemented at the AGH University of Science and Technology in Kraków (Poland) under the edition of Prof. Wojciech Górecki, together with the literature cited there and other 
thematically related studies (incl. [52,53]). Thermal, reservoir, petrophysical and hydrogeological parameters were considered within five designated depth intervals: 500-1000; 1000-1500, 1500-2000; 2000-2500; 2500-3500 m bsl and marked with letters from A to E, respectively. The $0-500 \mathrm{~m}$ bsl depth interval has been excluded from the analysis. Each of the aforementioned depth intervals has been analyzed for the average temperature, the thickness of water-bearing horizons, expected boreholes' capacities, water mineralization and type [54,55], as well as subsequent parameters of hydraulic conductivity, effective porosity, permeability and shale content. The petroleum characteristics of the analyzed region have been made upon information available in scientific studies and publications (incl. $[52,53,56])$. The attention has been paid mainly to natural gas deposits, treating Miocene crude oil reservoirs as a secondary matter. The Miocene reservoir rocks [57], as well as hydrocarbon traps and paths for gas migration [58], have been presented. Additionally, the current development state and stages of production of individual Miocene deposits located in the analyzed area have been identified [59]. In order to estimate the deposition depth of natural gas deposits, the available borehole data have been analyzed [60-62]. The aforementioned data was processed using the publicly available GIS program. Based on the depth data $[60,61]$ concerning boreholes of the selected deposit, the average depth of the considered reservoir has been estimated (Equation (1)). The resulting depths were also verified with literature data (incl. $[51,63,64]$ ), inter alia, to verify the correctness of taken actions.

$$
\mathrm{x}=\left(\mathrm{h}_{\min }+\mathrm{h}_{\max }\right) / 2
$$

where $\mathrm{x}$-arithmetic average depth of deposits of hydrocarbon $[\mathrm{m}], \mathrm{h}_{\min }$-minimal depth of borehole within selected deposit $[\mathrm{m}], \mathrm{h}_{\max }$ - maximum depth of borehole within selected deposit [m].

Then, supposed geothermal parameters (i.e., geothermal intervals) have been assigned to average deposits' depths, paying special attention to temperature data as a criterion for the elimination of areas from further analysis. This, in turn, enabled the identification of natural gas regions within the autochthonous Miocene formation, which may be structures/regions with a great potential for the implementation of technology that is focused on the exploitation of geothermal energy. Additionally, in order to show the general characteristics of hydrocarbon deposits occurring in the analyzed area, a few selected gas deposits have also been described (i.e., [51,65]). The deposits along the Carpathian Overthrust have been selected, either small (e.g., Jodłówka; [64]) and of considerable size (i.e., Przemyśl; [66]).

\section{General Characteristics of the Analyzed Area}

\subsection{Location}

Within the administrative borders of Poland, the Carpathian Foredeep mainly covers three voivodeships (Figure 1). Starting from the eastern border of the country: the northern part of the Subcarpathian voivodeship as well as fragments of the Lesser Poland and Silesian voivodeships. The most peripheral areas of the Carpathian Foredeep cover a part of the Holy Cross Province (in the North), a small area of the Opole Voivodeship in the West, while in the East, mildly entering the Lublin Voivodeship (Figure 1).

When considering the geographical and geological aspects, the northern boundary of the Carpathian Foredeep is determined by the extent of the Neogene formations, while the southern border is along the overlap of the Outer Carpathians. Its latitudinal extent reaches over $300 \mathrm{~km}$, and the maximum width does not overdraw $100 \mathrm{~km}$ (Figures 1 and 2) [50]. According to the physico-geographical division adopted by Kondracki [47], the area of the Carpathian Foredeep largely belongs to the Northern Subcarpathia. In the southern part, it covers a part of the Outer Western Carpathians, while in the northern part, it is the Silesian-Cracow and Lesser Poland Upland [47]. Within the Northern Subcarpathia, the Oświęcim Basin, the Krakow Gate and the Sandomierz Basin are distinguished. The area of the Carpathian Foredeep also includes a small area of the Ostrava Basin (in the western part), and the Rzeszów Piedmont stands out in the east. The Nida Basin belonging 
to Lesser Poland extends north-eastwards of Kraków, whereas to the north-west of the city, there is the Silesian Upland, which constitutes the part of the Silesian-Cracow Upland.

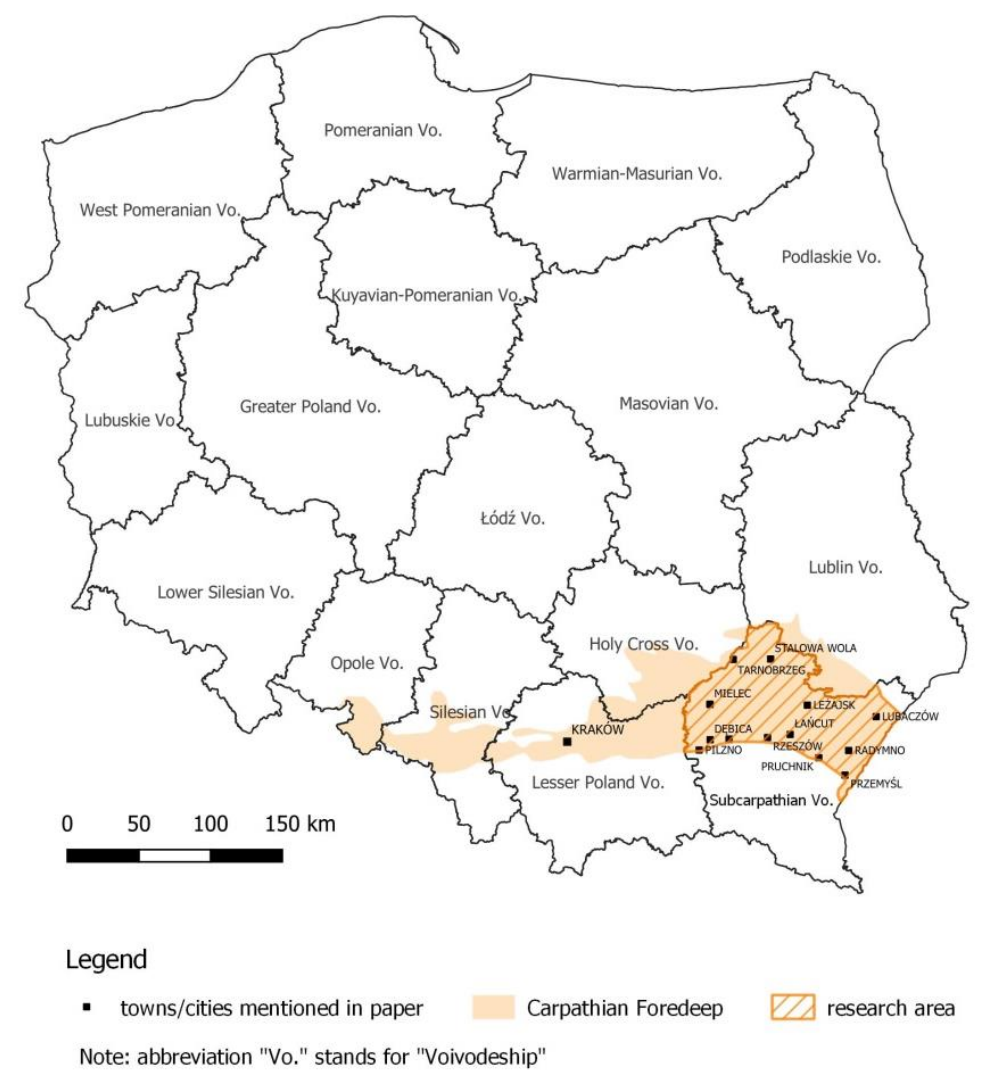

Figure 1. Administrative map of Poland with research area (based on [62]).

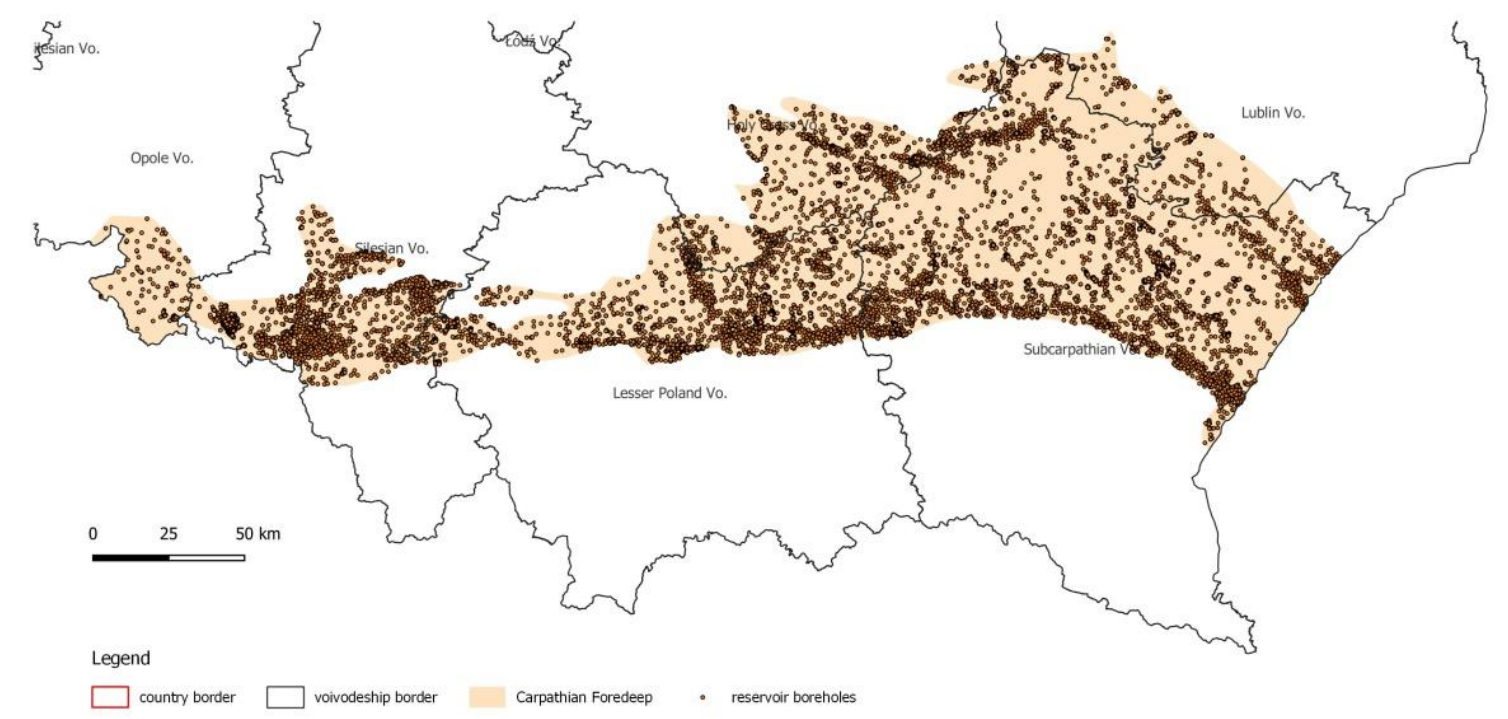

Figure 2. The Polish part of Carpathian Foredeep with all boreholes (based on [60,62]).

The geothermal-petroleum analysis has been conducted within the eastern part of the Carpathian Foredeep, limiting the research area from the south with the Carpathian Overthrust, while the other borders coincide with the reach of the Subcarpathian Voivodeship (Figure 1). 


\subsection{Geological Background}

The Carpathian Foredeep is the Neogene structure genetically associated with the youngest geological unit of Poland, namely, the Flysch Carpathians [50]. It constitutes an asymmetrical structure filled with Miocene molasses (Figure 3), with a thickness reaching over $3000 \mathrm{~m}$ (in so-called Wielkie Oczy Graben), originating mainly from the erosion of folded deposits of Carpathian Flysch [67]. Neogene sediments of the Carpathian Foredeep lie on various-age basements, from Precambrian to Cretaceous, and on different tectonic units: Variscan and Laramian [49]. Generally, they are in the form of shale, siltstone and sandstone sequences, forming the complex of so-called autochthonous Miocene [50]. The formations are generally undisturbed and lie relatively flat $\left(0-15^{\circ}\right)$, adapting their structural arrangement to the relief of the Precambrian-Palaeozoic basement (Lesser Poland Block) [51]. The maximum thickness of Miocene deposits occurs in the southern part and decreases towards the north (Figure 3). The age of the autochthonous Miocene is determined as the Badenian-Sarmatian period [51]. The autochthonous Miocene profile of the analyzed part of the Carpathian Foothills begins with clay and sandy sediments, the so-called Baranów Beds. In lithological terms, they are usually green or gray-green clay shales interlaced with marls and glauconite sandstones. Their thickness is from several to even $70 \mathrm{~m}$ (Lubaczów). In the more northern part, the lowest level of Lower Badenian is represented by lithotamine limestones (i.e., area of Cetynia, Lubaczów and Dzików) [57]. Above the Baranów Beds, there is a series of evaporate sediments (called the Krzyżanowice Formation), which is of great importance as the main correlation level and seismic marker in the scale of the entire Carpathian Foredeep. Evaporate sediments with a thickness of up to $60 \mathrm{~m}$ are mainly anhydrite, sometimes gypsum as well as primary and epigenetic limestone with sulfur mineralization. In the region northwards from Rzeszów (the so-called Rzeszów Ridge) there are no anhydrite formations. It was caused by erosion, which removed at least 50-100 m of chemical and older Neogene sediments [68]. In the Lubaczów region (exactly the Dzików hydrocarbons deposit), a limestone complex with a dark gray mudstone deposit of several centimeters was found. These layers correspond to the anhydrite series [57]. The over-anhydrite Miocene of the Upper Badenian and Sarmatian is a seemingly monotonous clay-sandy series with a total thickness of up to $2500 \mathrm{~m}$ [57]. Generally, it can be said that the Upper Badenian deposits are more clayishthey are formed by a complex of gray-green shales (over-gypsum/spirilisal level) with a thickness between 30 and $180 \mathrm{~m}$. Within this formation, there are also thin sandstone and bentonite or tufit inserts. On the other hand, the Lower Sarmatian formations begin with a packet of sandstone-shale layers with a thickness of several hundred meters, and above, they pass into a silty-sandy series with a predominance of slate. Due to much local demarking, they are most often referred together as the Machów Formation [57]. Among the sediments included and occurring in the eastern part of the Carpathian Foredeep, the spirilisal-pectoral clay Krakowiec Beds should be mentioned. The top part of the latter is sometimes attributed to the Pannonian age [69]. 


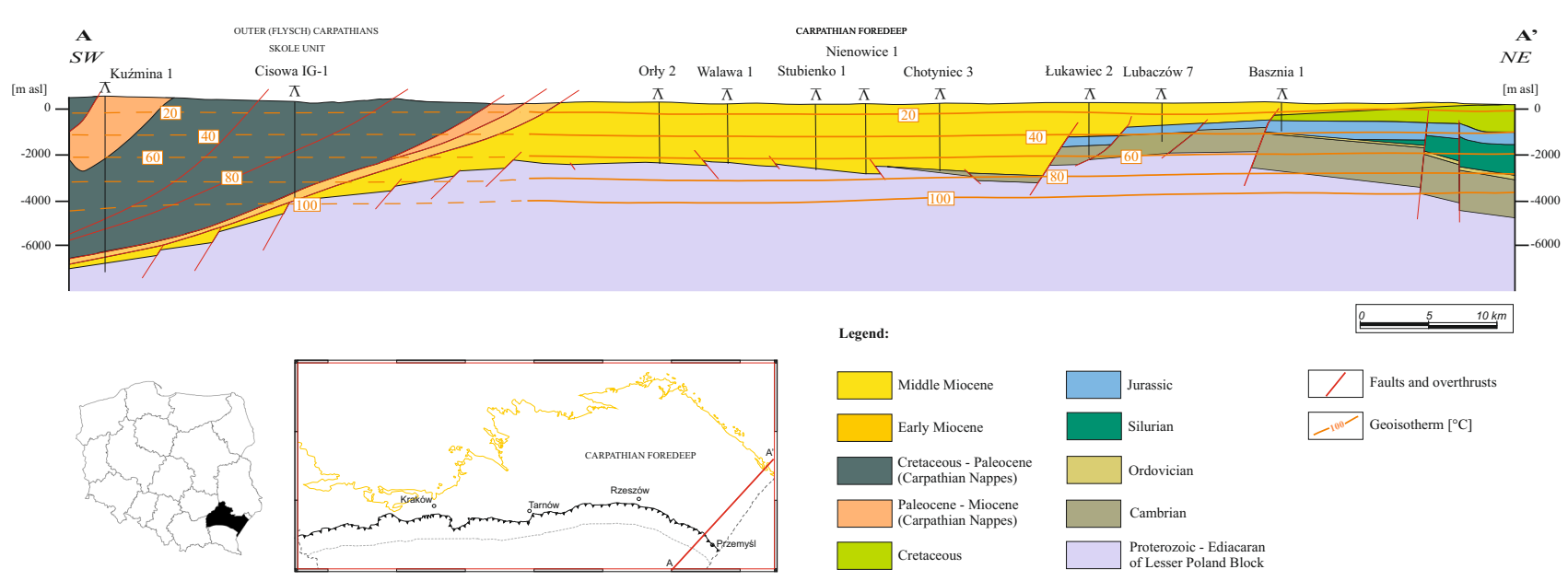

Figure 3. Exemplary geological cross-section through the east part of Carpathian Foredeep (based on $[49,50,70]$ ).

\section{Geothermal Characteristics of the Analyzed Area}

Due to the specific geological structure and therefore different hydrothermal characteristics, four major geothermal provinces can be distinguished in Poland $[38,45,46]$. The largest in the area and most prospective in terms of heat and/or energy production is a province of the Polish Lowlands. Similar importance is assigned to the Podhale region, located within the Carpathian Geothermal Province. Different but also favorable geothermal conditions are found in the Sudetic Geothermal Region, where geothermal waters occur in the crystalline formations of the Sudetes. However, this paper concerns the fourth geothermal province, namely, the Fore-Carpathian Province.

The Fore-Carpathian Province is located in the southern part of Poland, covering the geological structure of the Polish part of the Carpathian Foredeep. The area of the Carpathian Foredeep covers $24,400 \mathrm{~km}^{2}$, which constitutes $7.8 \%$ of Polish territory [50]. The area is relatively well explored (over 3000 boreholes within the analyzed area) due to the years-lasting production of hydrocarbons deposits (Figure 2), thus, there was a possibility to assess the geothermal potential of this region. Geothermal research was made within Triassic, Jurassic, Cretaceous Miocene formations [50]. However, in this paper, only the autochthonous Miocene formation is discussed. The analysis of geothermal reservoir within the autochthonous Miocene has been carried out based on subsequent parameters that are presented in a few following sub-sections.

\subsection{Miocene Thickness}

The autochthonous Miocene is characterized by the high variability of reservoir parameters resulting, inter alia, from the depth of its deposition. The deepest Miocene deposits are located in the south-eastern and southern part of the determined area of the Carpathian Foredeep, reaching maximum values of over $4000 \mathrm{~m}$ bsl, under the Carpathian Overthrust (Figure 4). Therefore, the noticeable change of Miocene's thickness is observed, from sizeable exactly under and northwards the Carpathian Overthrust to smaller in the North [71,72]). The largest thickness of the Miocene is marked north-east of Przemyśl, where it locally exceeds $3000 \mathrm{~m}$. The Miocene of a considerable thickness occurs also in the area of large cities in the southern part of the analyzed area, i.e., Rzeszów, Dẹbica and Ropczyce-which can be considered as potential heat consumers. The smallest thickness of Miocene formation does not exceed $100 \mathrm{~m}$. Besides the varying thickness of Miocene deposits, the top surface is an exact reflection of the base, and in the vast part of the area, it is located above sea level.

As aforementioned, due to the considerable thickness of Miocene deposits and high variability of the form of separate stratigraphic stages, five depth intervals have been determined and a specific analysis of geothermal parameters has been made. 


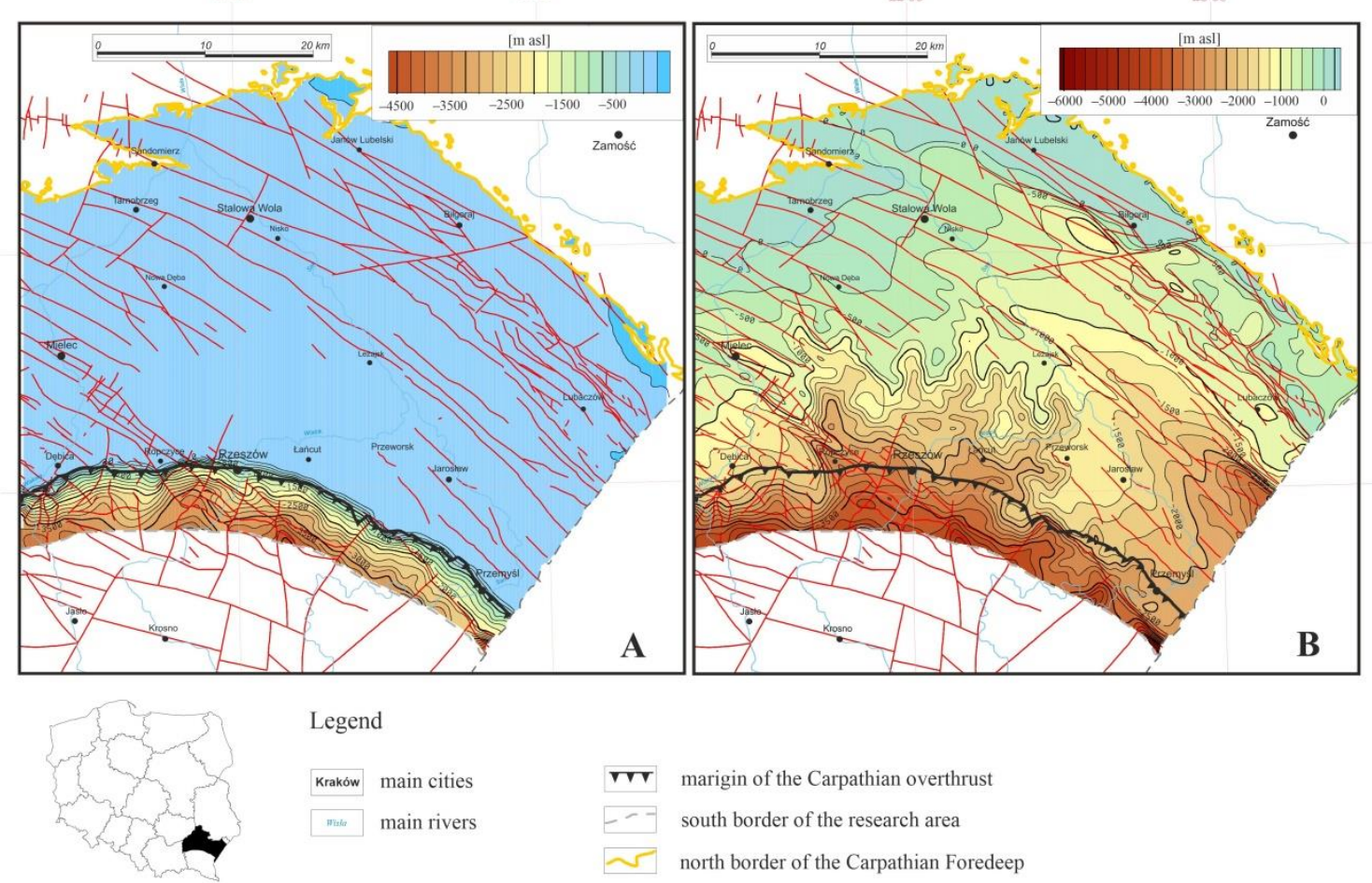

Figure 4. Top (A) and base (B) of the autochthonous Miocene within the research area (based on [50]).

\subsection{Thermic Parameters}

The analyzed area of the Carpathian Foredeep, for all having good drilling reconnaissance (Figure 2), is fairly average in terms of thermal recognition [50]. Generally, the thermal regime is of a regional character and usually concerns studies nationwide (incl. [73-77]). As stated by Górecki (eds.) [50], the interpretation of the thermal field in this region is the result of the interpolation of thermal data from wells located outside the Carpathian Foredeep, rather than in situ measurements. More detailed studies on the area's geothermal energy have so far been carried out in smaller areas (e.g., for the Subcarpathian Voivodeship [78] or were of point-nature such as cities/municipalities (e.g., for Pilzno, Dębica, Mielec, Przemyśl, Jarosław, Łańcut or Rzeszów (Figure 1)) [78,79]). In the Geothermal Atlas of Carpathian Foredeep [50], a thermal analysis has been made based on the interpretation of the available results of measurements of the maximum temperature at the bottom of the borehole (so-called bottom hole temperature, abbr. BHT). Due to the uneven distribution of data (most measurements have been conducted along the Carpathian Overthrust) and errors resulting from the method of measuring temperatures in the boreholes (transient conditions), corrective and climatic corrections were introduced and data interpolation was performed on the area of Carpathian Foredeep [50]. As the effect, the heat flux within the analyzed area presents relatively low values between $65.0-76.6 \mathrm{~mW} / \mathrm{m}^{2}$ in the eastern part, while in the western part, these values oscillate between $75.0-87.5 \mathrm{~mW} / \mathrm{m}^{2}$ in front of the Carpathian Overthrust and decrease northwards to the value of $60.0-65.0 \mathrm{~mW} / \mathrm{m}^{2}$. The average estimated values of the geothermal gradient show an increasing trend from the north-east towards the southwest, reaching values between 1.72 and $2.4{ }^{\circ} \mathrm{C} / 100 \mathrm{~m}$ (in the region of Rzeszów).

\subsection{Temperatures}

The deep location of Miocene deposits has a positive effect on the temperatures prevailing in the reservoir. The very first depth interval was set from the top of autochthonous Miocene to $500 \mathrm{~m} \mathrm{bsl}$, but as the temperature does not exceed $20^{\circ} \mathrm{C}$ [80], the presence of geothermal waters has been excluded, and ipso facto, its further analysis has been ceased. 
Generally, within the five remaining intervals (marked as A-E), the temperatures are rising along with a growth of depth. The temperatures for the center of each interval are presented in Figure 5. The highest temperatures (of around $80-100{ }^{\circ} \mathrm{C}$ ) are to be expected at a depth of approximately $3000 \mathrm{~m}$, in the eastern part of the analyzed area.

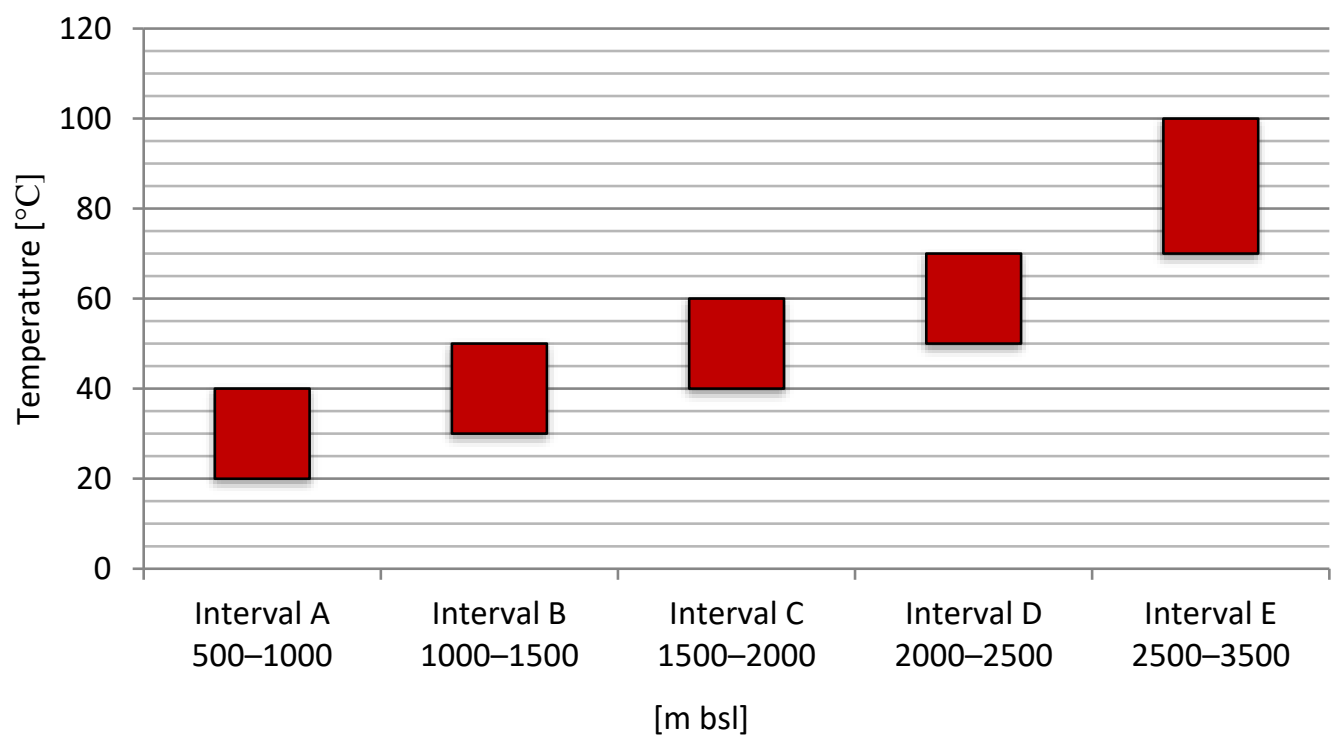

Figure 5. Approximate temperatures for each considered depth interval (based on [50]).

\subsection{Water-Bearing Horizons}

The water-bearing horizons of the Miocene in the eastern part of the Carpathian Foredeep are generally discontinuous, because Miocene sandstones as reservoir rocks often have the form of lenses and pinching out layers. However, they are simultaneously characterized by considerable thicknesses. The summarized thickness of aquifers within interval A is considered the highest as the value reaches up to $300 \mathrm{~m}$ (between Przeworsk and Leżajsk). Two distinct lenses with thicknesses of around $200 \mathrm{~m}$ and $250 \mathrm{~m}$ are located northwards from Ropczyce and Leżajsk, respectively. In the case of interval B, one can observe three areas with thicker aquifers-up to $150 \mathrm{~m}$ near Rzeszów and Łańcut, and up to $200 \mathrm{~m}$ near Debica town. Interval $\mathrm{C}$ consists of two lenses with summarized thicknesses exceeding $100 \mathrm{~m}$, directly under the Carpathian Overthrust, just between Rzeszów and Przemyśl towns. Within the next formation, there are no significant aquifers. Regions with higher thicknesses (between 50-75 m) of water-bearing horizons are located eastwards Jarosław town, close to the Polish border. In the remaining 2500-3500 m interval, there is the area of a summarized thickness of aquifers up to a maximum of $200 \mathrm{~m}$ (between Ropczyce and Rzeszów towns, exactly under the Carpathian Overthrust).

\subsection{Boreholes' Capacities}

Generally, the low capacity of boreholes constitutes the essential problem in the autochthonous Miocene reservoir, where zones with the increased potential of wells' capacities occur only locally [52,53]. The zones of intensified boreholes' capacities reflect the occurrence of aquifers of considerable thickness. Thus, the minimum $\left(\mathrm{Q}_{\min }\right)$ and maximum $\left(\mathrm{Q}_{\max }\right)$ values of boreholes' capacities within the analyzed area are presented in Table 1. 
Table 1. Average and maximum capacities of boreholes (Q) dependent on the depth interval (based on [50]).

\begin{tabular}{|c|c|c|c|c|}
\hline \multicolumn{2}{|c|}{ Determined Intervals } & \multirow{2}{*}{$\mathrm{Q}_{\min }\left[\mathrm{m}^{3} / \mathrm{h}\right]$} & \multicolumn{2}{|r|}{$\mathrm{Q}_{\max }$} \\
\hline Symbol & Depth [m bsl] & & Value $\left[\mathrm{m}^{3} / \mathrm{h}\right]$ & Location \\
\hline A & $500-1000$ & $0-10$ & $130-140$ & north-east direction from Leżajsk \\
\hline $\mathrm{B}$ & $1000-1500$ & $0-10$ & $40-50$ & north- and eastwards from Rzeszów \\
\hline $\mathrm{C}$ & $1500-2000$ & $0-10$ & $30-40$ & half-way from Rzeszów to Przemyśl \\
\hline $\mathrm{D}$ & $2000-2500$ & $0-10$ & $30-40$ & eastwards from Jarosław town \\
\hline $\mathrm{E}$ & $2500-3500$ & $0-10$ & $20-30$ & near Ropczyce town \\
\hline
\end{tabular}

\subsection{Total Dissolved Solids}

Simultaneously, as the temperatures of separate intervals increase, the values of total dissolved solids (abbr. TDS) also rise. Within the first analyzed depth interval (A; 500-1000 m bsl), the TDS of hardly the whole area does not exceed $50 \mathrm{~g} / \mathrm{dm}^{3}$. Only locally, northwards from Rzeszów and Lubaczów, do TDS values vary between $50-75 \mathrm{~g} / \mathrm{dm}^{3}$. The waters of interval B are characterized by similar mineralization, from $25 \mathrm{~g} / \mathrm{dm}^{3}$ in Przemyśl area, rising in the north-west direction, to $100 \mathrm{~g} / \mathrm{dm}^{3}$ in the most western part of the research area. Additionally, interval C presents values between $50 \mathrm{~g} / \mathrm{dm}^{3}$ (SE part) and $100 \mathrm{~g} / \mathrm{dm}^{3}$ (SW part). Considering the following depth intervals, the maximum TDS values occur in the southern-western part of the analyzed area and reach nearly $200 \mathrm{~g} / \mathrm{dm}^{3}$.

Below the freshwater, there are saline, sulfate or hydrogen sulfide waters [55]. Most of the water accumulated in the Miocene reservoir at all designated depth intervals is chloride water; mainly $\mathrm{Cl}-\mathrm{Na}$ or, to a lesser extent, the $\mathrm{Na}-\mathrm{Cl}$ type. The $\mathrm{Na}-\mathrm{Cl}-\mathrm{HCO}_{3}$ chemical type waters are much less common-such can be found primarily in Mielec, Ropczyce, Łańcut and Jarosław surroundings. The presence of waters with the chemical composition $\mathrm{Cl}-\mathrm{Na}-\mathrm{Ca}$ is marked in a few places. Additionally, in the waters of the autochthonous Miocene formation, within the studied area, the presence of specific components relevant for the therapeutic use of waters was found; among others, iodine, bromide or sulfur compounds [54]. Moreover, abnormal concentrations of iodides, bromides and metasilicic acid are found in edge waters of hydrocarbon deposits, or in areas where mixing with relict waters is possible [81].

\subsection{Reservoir Parameters}

In this paragraph, information concerning hydraulic conductivity effective porosity, permeability and shale volume within discussed depth intervals of autochthonous Miocene have been correlated. Generally, along with the depth, the parametric recognition of rocks decreases, and the diversity of values is quite large [50]. This is related to, among others, the variability of the broadly understood geological structure, lithological form of rocks or the degree of structures' transformation. Interval A is characterized by the best values of hydraulic conductivity, reaching up to $50 \times 10^{-5} \mathrm{~m}^{2} / \mathrm{s}$ in Leżajsk town. Additionally, the filtration coefficient presents the highest values (over $2 \times 10^{-4} \mathrm{~m} / \mathrm{s}$ ) and effective porosity is set as $20 \%$. Within this interval, the fields of high permeability (exceeding $100 \mathrm{mD}$ ) occur in the southern and eastern parts of the analyzed area. Apparently, the occurrence of shaly minerals within the aquifer is arranged inversely in relation to the conductivity and permeability parameters. In the discussed depth interval, it takes values from $20 \%$ (in the Lubaczów area) to $45 \%$. The most frequent values belong to the range from $30-35 \%$ and cover the majority of the study area. Similar parameters can be found in the next depth interval. Namely, permeability and effective porosity maximum values are over $100 \mathrm{mD}$ and $15 \%$, respectively. However, hydraulic conductivity reaches more than $15 \times 10^{-5} \mathrm{~m}^{2} / \mathrm{s}$ in the Rzeszów-Łańcut area. In this case, shale volume values hesitate between 25 and $45 \%$. However, the range of $35-40 \%$ is preponderant throughout the research area of this interval; values between $40-45 \%$ are the second. Reservoir parameters of deeper intervals are slightly less developed. At a depth between 1500 and $2000 \mathrm{~m}$, the permeability of the Miocene aquifer does not exceed $100 \mathrm{mD}$ and the maximum hydraulic conductivity 
(half the way from Rzeszów to Przemyśl) does not reach the value of $10 \times 10^{-5} \mathrm{~m}^{2} / \mathrm{s}$. The effective porosity in the Rzeszów-Przemyśl-Jarosław region ranges between 5-15\%. Whereas the content of shale rocks presents values from $30 \%$ to even $45 \%$, however, the biggest area presents values between $35 \%$ and $40 \%$. The interval D, like the previous one, is characterized by quite good values of hydraulic conductivity (max. $12 \times 10^{-5} \mathrm{~m}^{2} / \mathrm{s}$ eastwards Jarosław town), permeability (up to $100 \mathrm{mD}$ ) and effective porosity (up to $15 \%$ ). The shale volume of the aquifer varies between 25\% (area between Przemyśl and Lubaczów) and $45 \%$, whereas the most frequent values belong to the range 35-40\% (e.g., Rzeszów city area). The last but not least depth interval presents higher values of reservoir parameters between Ropczyce and Rzeszów, directly under the Carpathian Overthrust. They are as follows: permeability—up to $30 \mathrm{mD}$, hydraulic conductivity-max. $16 \times 10^{-5} \mathrm{~m}^{2} / \mathrm{s}$, and effective porosity - slightly exceeding $10 \%$ ). If it comes to shale content, the smallest values of $25-30 \%$ are determined in the aforementioned area, whereas, the maximum ones (and prevailing within the area) reach $45 \%$ in the area between Eańcut town and Przemyśl city, along the Carpathian Overthrust.

\section{Petroleum Characteristic of the Analyzed Area}

The Carpathian Foredeep is part of the second-biggest petroleum province in Poland, namely, the Lesser Poland (Carpathians) Petroleum Province. The natural gas resources are connected with Jurassic, Cretaceous and Miocene formations, however, natural gas is produced predominantly from the Miocene reservoir (Figure 6) [37]. It is usually high-methane low-nitrogen gas, and only a few deposits contain nitrogen-rich natural gas [56,59,82]. The deposits belong to the structural-lithological type, multi-layered, less often massive, producing in gas-pressure conditions. Subcarpathian natural gas deposits have elasticexpansion-hydroconfined energy conditions [56]. Crude oil deposits of the Carpathian Foredeep are connected primarily to Mesozoic sedimentary formations-mainly carbonate Jurassic formations, less often Cretaceous sandstones, placed under the sealing clayey Miocene [59]. Nonetheless, the autochthonous Miocene constitutes a minor reservoir for oil deposits (Figure 6). In the analyzed area, there are mostly stratified deposits shielded stratigraphically, lithologically or tectonically.

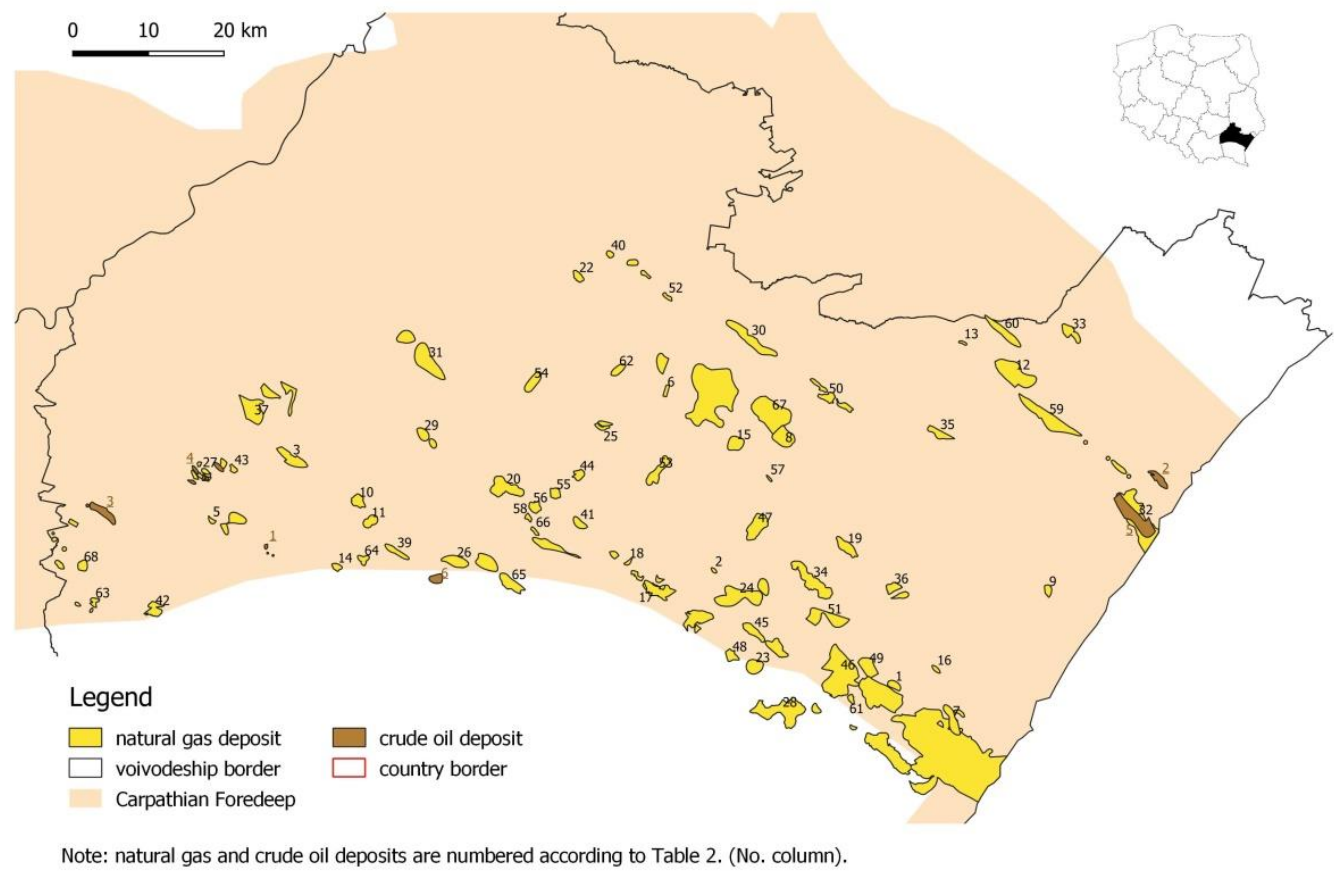

Figure 6. Natural gas and crude oil fields within the autochthonous Miocene of Carpathian Foredeep (based on [60-63]). 
In the autochthonous Miocene of the Carpathian Foredeep, over 100 deposits of natural gas (exactly 105 as of March 2020 [59]) were discovered, both large deposits with multi-billion reserves made available for production, as well as small never-used accumulations. There are 69 natural gas deposits within the analyzed area (Table 2, Figure 6), including the largest deposits as Przemyśl (No. 46), Lubaczów (No. 32), and many other fields. Discussing crude oil resources, there are barely six deposits (out of twelve located in the Carpathian Foredeep) within the analyzed area (Table 2, Figure 6); thus, their significance for this study has been considered minor. Nonetheless, it is worth mentioning that exploration work (mainly gas-oriented) is still underway in the considered area, as well as the whole Carpathian Foredeep $[37,83]$.

Table 2. The overall characteristic of oil and gas deposits within the analyzed area (based on [59]).

\begin{tabular}{|c|c|c|c|c|c|c|c|}
\hline \multirow{3}{*}{ No. } & \multirow{3}{*}{ Field's Name } & \multirow{3}{*}{$\begin{array}{c}\text { Deposit } \\
\text { Development } \\
\text { State }\end{array}$} & \multicolumn{4}{|c|}{ Deposits [Million $\mathrm{m}^{3}$ ] } & \multirow{3}{*}{ Production } \\
\hline & & & \multicolumn{3}{|c|}{ Exploitable Recoverable/Off-Balance (p) } & \multirow{2}{*}{ Industrial } & \\
\hline & & & Altogether & $A+B$ cat. & C cat. & & \\
\hline \multicolumn{8}{|c|}{ Natural Gas } \\
\hline 1 & Batycze & $\mathrm{E}$ & 9.37 & - & 9.37 & 5.37 & 3.14 \\
\hline 2 & Białoboki & $\mathrm{E}$ & 39.61 & - & 39.61 & 23.61 & 2.67 \\
\hline 3 & Blizna-Ocieka & $\mathrm{T}$ & 119.95 & - & 119.95 & 33.19 & - \\
\hline 4 & Brzezówka & $\mathrm{E}$ & 15.65 & 15.65 & - & 0.29 & 0.21 \\
\hline 5 & Brzeźnica & G & 45.59 & 45.59 & - & 45.59 & - \\
\hline 6 & Brzóza Królewska & $\mathrm{R}$ & 24.00 & - & 24.00 & - & - \\
\hline 7 & $\begin{array}{c}\text { Buszkowiczki } \\
\text { (Przemyśl) }\end{array}$ & $\mathrm{E}$ & 143.14 & 24.00 & 119.14 & 28.94 & 6.75 \\
\hline 8 & Chałupki Dębniańskie & $\mathrm{E}$ & 155.10 & 79.43 & 75.67 & 13.67 & 8.74 \\
\hline 9 & Chotyniec & $\mathrm{P}$ & 40.00 & - & 40.00 & - & - \\
\hline 10 & Cierpisz & $\mathrm{E}$ & 678.78 & - & 678.78 & 242.11 & 10.88 \\
\hline 11 & Czarna Sędziszowska & $\mathrm{E}$ & 32.93 & - & 32.93 & 12.51 & 0.01 \\
\hline 12 & Dzików & $\mathrm{E}$ & 848.91 & 282.37 & 566.54 & 96.47 & 66.17 \\
\hline 13 & Dzików Stary & $\mathrm{B}$ & 15.27 & - & 15.27 & 15.27 & - \\
\hline 14 & Góra Ropczycka & $\mathrm{E}$ & 116.66 & - & 116.66 & 79.94 & 4.00 \\
\hline 15 & Grodzisko Dolne & $\mathrm{E}$ & 108.25 & - & 108.25 & 59.68 & 2.05 \\
\hline 16 & Gubernia & $\mathrm{E}$ & 0.56 & 0.56 & - & - & 0.39 \\
\hline 17 & Husów & G & 372.88 & 372.88 & - & 372.88 & - \\
\hline 18 & $\begin{array}{c}\text { Husów-Albigowa- } \\
\text { Krasne }\end{array}$ & E & 1460.07 & 201.21 & 1258.86 & 327.37 & 21.44 \\
\hline 19 & Jarosław & $\mathrm{E}$ & 810.54 & 765.07 & 45.47 & 68.23 & 6.26 \\
\hline 20 & Jasionka & $\mathrm{E}$ & 992.79 & - & 992.79 & 514.6 & 31.58 \\
\hline 21 & Jastrząbka Stara & $\mathrm{E}$ & 0.63 & 0.63 & - & 0.21 & 0.05 \\
\hline 22 & Jeżowe NW & $\mathrm{E}$ & $12.48(\mathrm{p})$ & $-(p)$ & $12.48(\mathrm{p})$ & 8.79 & 0.62 \\
\hline 23 & Jodłówka & $\mathrm{E}$ & 964.13 & 864.05 & 100.08 & 53.34 & 5.31 \\
\hline 24 & Kańczuga & $\mathrm{E}$ & 36.35 & 30.87 & 5.48 & 21.77 & 3.62 \\
\hline 25 & Kąty Rakszawskie & $\mathrm{E}$ & 15,67 & - & 15.67 & 8.62 & 0.43 \\
\hline 26 & Kielanówka-Rzeszów & $\mathrm{E}$ & 2081.26 & 742.9 & 1338.36 & 99.68 & 52.98 \\
\hline 27 & Korzeniów (gaz) & $\mathrm{Z}$ & $6.57(\mathrm{p})$ & $-(p)$ & $6.57(p)$ & - & - \\
\hline 28 & Kramarzówka & $\mathrm{P}$ & 1272.89 & - & 1272.89 & 1129.52 & - \\
\hline 29 & Kupno & $\mathrm{E}$ & 98.53 & - & 98.53 & 51.64 & 3.84 \\
\hline 30 & Kuryłówka & $\mathrm{E}$ & 231.20 & 140.96 & 90.24 & 48.38 & 18.99 \\
\hline 31 & Lipnica-Dzikowiec & $\mathrm{R}$ & 154.00 & 101.00 & 53.00 & - & - \\
\hline 32 & Lubaczów & $\mathrm{E}$ & 361.13 & 166.82 & 194.31 & 8.85 & 29.91 \\
\hline 33 & Lubliniec-Cieszanów & $\mathrm{E}$ & 174.36 & - & 174.36 & 87.3 & 14.64 \\
\hline 34 & Mirocin & $\mathrm{E}$ & 383.74 & 321.92 & 61.82 & 151.69 & 44.53 \\
\hline 35 & Mołodycz & $\mathrm{E}$ & 87.92 & - & 87.92 & 58.09 & 1.01 \\
\hline 36 & Morawsko & $\mathrm{E}$ & 183.03 & - & 183.03 & 26.84 & 3.15 \\
\hline 37 & Niwiska & $\mathrm{Z}$ & $21.00(\mathrm{p})$ & $21.00(p)$ & $-(p)$ & - & - \\
\hline 38 & Nosówka & $\mathrm{E}$ & 3.99 & 3.99 & - & 4.40 & 0.51 \\
\hline 39 & Nosówka (gaz) & $\mathrm{E}$ & 376.91 & 170.24 & 206.67 & 148.82 & 8.16 \\
\hline 40 & Nowosielec & $\mathrm{E}$ & 72.86 & - & 72.86 & 28.98 & 0.94 \\
\hline 41 & Palikówka & $\mathrm{E}$ & $626, .99$ & 73.83 & 553.16 & 122.88 & 9.92 \\
\hline
\end{tabular}


Table 2. Cont.

\begin{tabular}{|c|c|c|c|c|c|c|c|}
\hline \multirow{3}{*}{ No. } & \multirow{3}{*}{ Field's Name } & \multirow{3}{*}{$\begin{array}{c}\text { Deposit } \\
\text { Development } \\
\text { State }\end{array}$} & \multicolumn{4}{|c|}{ Deposits [Million $\mathrm{m}^{3}$ ] } & \multirow{3}{*}{ Production } \\
\hline & & & \multicolumn{3}{|c|}{ Exploitable Recoverable/Off-Balance (p) } & \multirow{2}{*}{ Industrial } & \\
\hline & & & Altogether & $A+B$ cat. & C cat. & & \\
\hline 42 & Pilzno Południe & $\mathrm{E}$ & 675.75 & 276.97 & 398.78 & 85.37 & 9.24 \\
\hline 43 & Podole & $\mathrm{E}$ & 8.93 & - & 8.93 & 7.84 & 0.75 \\
\hline 44 & Pogwizdów & $\mathrm{E}$ & 73.14 & - & 73.14 & 23.14 & 2.04 \\
\hline 45 & Pruchnik-Pantalowice & $\mathrm{E}$ & 992.86 & 11.48 & 981.38 & 490.96 & 50.92 \\
\hline 46 & Przemyśl & $\mathrm{E}$ & 7459.97 & 6529.38 & 930.59 & 245.37 & 435.70 \\
\hline 47 & Przeworsk & $\mathrm{E}$ & 312.02 & 45.64 & 266.38 & 173.55 & 41.17 \\
\hline 48 & Rączyna & $\mathrm{E}$ & 228.53 & 228.53 & - & 120.46 & - \\
\hline 49 & Rokietnica & $\mathrm{P}$ & 120.00 & - & 120.00 & - & - \\
\hline 50 & Rudka & $\mathrm{E}$ & 127.18 & - & 127.18 & 25.43 & 8.34 \\
\hline 51 & Rudołowice & $\mathrm{P}$ & 400.00 & - & 400.00 & - & - \\
\hline 52 & Sarzyna & $\mathrm{E}$ & 40.42 & 20.01 & 20.41 & 24.40 & 0.60 \\
\hline 53 & Smolarzyny & $\mathrm{E}$ & 84.51 & 39.75 & 44.76 & 11.12 & 2.94 \\
\hline 54 & Sokołów & $\mathrm{P}$ & 26.00 & - & 26.00 & - & - \\
\hline 55 & Stobierna & $\mathrm{E}$ & 161.52 & - & 161.52 & 150.39 & 2.04 \\
\hline 56 & Terliczka & $\mathrm{E}$ & 461.98 & - & 461.98 & 76.00 & 2.21 \\
\hline 57 & Tryńcza & $\mathrm{P}$ & 20.00 & - & 20.00 & - & - \\
\hline 58 & Trzebownisko & $\mathrm{E}$ & 335.47 & - & 335.47 & 149.63 & 0.33 \\
\hline 59 & Uszkowce & $\mathrm{Z}$ & - & - & - & - & - \\
\hline 60 & Wola Obszańska & $\mathrm{E}$ & 191.55 & 129.68 & 61.87 & 126.47 & 15.21 \\
\hline 61 & Wola Rokietnicka & $\mathrm{E}$ & 139.93 & - & 139.93 & 139.92 & 35.61 \\
\hline 62 & Wola Zarczycka & $\mathrm{P}$ & 16.00 & - & 16.00 & - & - \\
\hline 63 & Wygoda & $\mathrm{E}$ & 12.25 & 7.6 & 4.65 & - & 0.51 \\
\hline 64 & Zagorzyce & $\mathrm{E}$ & 94.57 & 58.31 & 36.26 & 24.05 & 11.22 \\
\hline 65 & Zalesie & $\mathrm{E}$ & 1756.11 & 1734.37 & 21.74 & 490.3 & 142.67 \\
\hline 66 & Załęże & $\mathrm{E}$ & 118.77 & - & 118.77 & 101.16 & 0.94 \\
\hline 67 & Żołynia-Leżajsk & $\mathrm{E}$ & 491.17 & 222.51 & 268.66 & 26.37 & 25.45 \\
\hline \multirow[t]{2}{*}{68} & Żukowice & $\mathrm{Z}$ & 96.72 & - & 96.72 & - & - \\
\hline & & & Crude Oil & & & & \\
\hline 1 & Brzezówka & $\mathrm{E}$ & 13.78 & 13.78 & - & 1.98 & 1.60 \\
\hline 2 & Cetynia & $\mathrm{Z}$ & $45.00(\mathrm{p})$ & $-(p)$ & $45.00(\mathrm{p})$ & - & - \\
\hline 3 & Jastrząbka Stara & $\mathrm{E}$ & 35.84 & 34.15 & 1.69 & 6.36 & 1.21 \\
\hline 4 & Korzeniów & $\mathrm{Z}$ & $5.93(\mathrm{p})$ & $-(p)$ & $5.93(\mathrm{p})$ & - & - \\
\hline 5 & Lubaczów & $\mathrm{P}$ & 115.93 & - & 115.93 & - & - \\
\hline 6 & Nosówka & $\mathrm{E}$ & 40.59 & 40.59 & - & 24.04 & 3.46 \\
\hline
\end{tabular}

Legend: B-prepared for extraction or trial operation; E-producing; G-underground gas storage (abbr. UGS); P-deposit with initially recognized resources (category $\mathrm{C}$, i.e., the relative error in estimating the average values of the deposit and resource parameters may be more than $30 \%$ ); $\mathrm{R}$-deposit with detailed recognized resources (category A + B, i.e., the relative error in estimating the average values of the deposit and resource parameters should be no more than 30\% (cat. B) and 15\% (cat. A)); Z-mining ceased; T—developed deposit, exploited periodically. Note: The deposit order numbers presented in the table above are referred to on the maps and within the text (in the form of brackets), each time that the name of the deposit is quoted.

The general characteristic of all 69 natural gas fields and 6 crude oil deposits is presented, however, deposit's development state (Figure 7) is of vital importance. The percentage distribution of the current development state of determined deposits within the analyzed area (Figure 7) shows that most of the deposits of both natural gas (51 fields) and crude oil (3 fields) are nowadays exploited, and the concession issued by Ministry of the Environment is valid for several more years [61]. On the other hand, mining has been ceased in only one natural deposit, recently (Figure 7). It is worth highlighting that, in a long-time perspective, some of today's exploited hydrocarbon fields will be ceased and might be used for other purposes, e.g., geothermal. 
NATURAL GAS

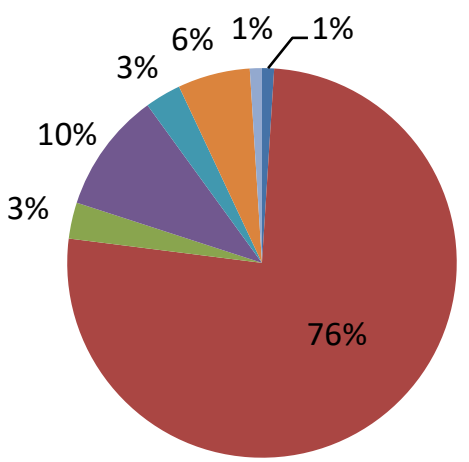

CRUDE OIL

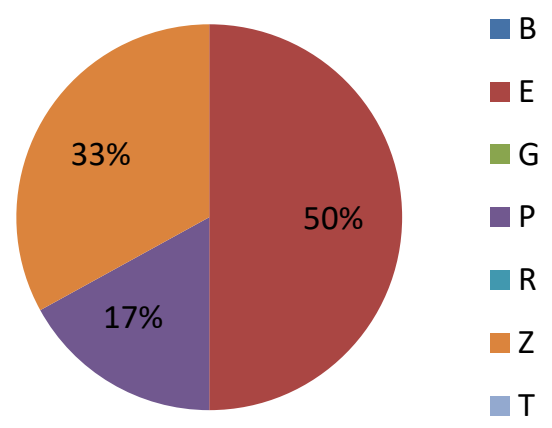

Figure 7. Percentage distribution of the development state of hydrocarbon deposits (based on [59]). Legend: B-prepared for extraction or trial operation; E-exploited; G-underground gas storage (abbr. UGS); $\mathrm{P}$-deposit with initially recognized reserves (category $\mathrm{C}$, i.e., the relative error in estimating the average values of the deposit and resource parameters may be more than $30 \%$ ); $\mathrm{R}$ deposit with detailed recognized reserves (category $\mathrm{A}+\mathrm{B}$, i.e., the relative error in estimating the average values of the deposit and resource parameters should be no more than $30 \%$ (cat. B) and $15 \%$ (cat. A)); Z-mining ceased; T-developed deposit, exploited periodically.

\subsection{Miocene Reservoir Rocks}

Miocene reservoir rocks are very diverse in lithological, petrographic and facial terms [57]. Often, a given region, deposit and even a borehole or a single gas horizon have their specific characteristics. In this connection, several main types are distinguished, which differ in age, lithology and facial origin and at the same time have serious industrial significance. In general, Baranów Beds' sandstones and transformed anhydrite are considered reservoir rocks among the Badenian sediments. In the Sarmatian sediments, deposition environments containing natural gas accumulating rocks have been separated, namely, turbidite sediments of submarine fans, delta sediments and shallow-sea sediments of estuaries, sandy barriers and lagoons [57]. Among the reservoir rocks, locally occurring Dzików sandstones are also distinguished. It is worth emphasizing that the Miocene reservoir rocks of the Carpathian Foredeep, even though they are almost exclusively sand-clay sediments, are characterized by the high variability of reservoir parameters depending on the environment in which they arose [49].

Baranów sandstones are the oldest reservoir rocks of relatively low operational significance due to their low thickness. Although the largest recorded thicknesses reach $70 \mathrm{~m}$, the most common are layers with a thickness between 3 and $10 \mathrm{~m}$. Their porosity ranges between 5 and $25 \%$, and the obtained gas flows reached up to $600,000 \mathrm{Nm}^{3} /$ day. However, gas accumulations in Baranów Beds are not large in terms of resources. Hydrocarbon shows are known from the Uszkowce (No. 59) and Lubaczów (No. 32) regions, where natural gas is accumulated in the basement sediments and Baranów sandstones. The accumulation of the natural gas of industrial importance was found in the Kuryłówka (No. 30) and Sarzyna (No. 52) deposits. The composition of gas extracted from Baranów sandstones varies significantly, from the one occurring in the higher layers of the Mioceneit is nitrogen-rich. The nitrogen value in the Kuryłówka and Sarzyna deposits reaches 31\% and $20 \%$, respectively [84].

Among the evaporite sediments, hydrocarbon symptoms often occur in anhydrite, but the industrial significance of these accumulations remains marginal. Anhydrite, despite the low primary porosity, can be a secondary reservoir rock, with porosity reaching a dozen or so percent. It is associated with the processes of chemical influence of hydrocarbons on sulfates [85]. Chemical processes transform anhydrite into epigenetic limestones and marls. Primary limestones, which are equivalent to evaporates (Dzików natural gas field; No. 12/13), are also sometimes found. The composition of natural gas from the 
evaporate series is different from that of the Sarmatian age-it has a higher content of heavy hydrocarbons and contains small amounts of hydrogen sulfide.

Turbidite of the basin plain and submarine fans contains one of the most important types of reservoir rocks in the Carpathian Foredeep, namely, sandstones of submarine fans as well as distal sandy-mudy-clayish heterolitic beds of basin plain. Heterolitic beds occur in the lowest part of Sarmatian sediments and are characterized by clay and mudstone lithology. The porosity of sandstone inserts reaches $10 \%$, however, due to the high proportion of clay rocks, the effective thickness of deposit horizons is small. Gas capacities range from several thousand to over $200,000 \mathrm{Nm}^{3}$ per day. The composition of natural gas is typical for Sarmatian deposits and contains around $96-99 \%$ of methane. Reservoir rocks with much better parameters are turbidite deposits of radial submarine fans. They occur in significant numbers in the eastern part of the Carpathian Foredeep, their sandy forms are particularly widespread in the area along and directly below the Carpathian Overthrust zone. They are characterized by the same thin bedding, clear organization in the form of multiple sets of layers of considerable thickness, grain thickening upwards and the increasing thickness of sandy beds [57]. Some of the turbidite deposits with the thickest sandstone and conglomerate beds were formed in the zones of migrating channels of the upper submarine fan. They have the form of lenticular, thick beds with a thickness of several to a dozen meters [86]. Thicker sandstone beds of submarine fans are reservoir rocks for the Przemyśl (No. 46), Jodłówka (No. 23) or Husów-Albigowa-Krasne (No. 18) gas fields (Table 2; Figure 6). The porosity is up to $27 \%$ (on average $14 \%$ ), whereas the permeability reaches up to $500 \mathrm{mD}$. As a consequence, the natural gas (95-99\% of methane) production rate reaches up to $7,500,000 \mathrm{~m}^{3}$ daily. Towards the top of the profile, sediments of the turbidite submarine fans are gradually replaced by deltaic deposits. They are characterized by clay-sandy lithology with grain growing upwards, as well as vertical cyclicality of sediments. Hydrocarbon deposits occur in layers and irregular sandy bodiesin structural and lithological-stratigraphic traps. Sandy fillings of distribution channels are particularly predisposed to accumulate hydrocarbons, which transfer sediments to the head of the delta and estuaries [57]. In the deltaic deposits profile, the cyclical nature and multiple repetitions of sealing rock layers cause the hydrocarbon migration to stop and promote the formation of multilayer deposits [87]. Sandstones within the parasequence form thick, homogeneous packages with a thickness between 10-20 m. The average grain diameter and thickness initially show an upward trend, and in the top part, they present the reverse sequence. Each parasquence is well insulated in the top by clayey-mud [57]. Most of the thicker sandy packets $(2-5 \mathrm{~m})$ from the top parts of the delta parasquence in structurally elevated areas are gas saturated, creating multilevel deposits with significant discharges (e.g., the Biszcza deposit—above $700,000 \mathrm{Nm}^{3}$ /day). Porosity values are up to $32 \%$, whereas the conductivity reaches $900 \mathrm{mD}$. In addition, among the delta sediments of the Carpathian Foredeep, the occurrence of non-consolidated rocks (sands) and poorly consolidated sandstones, which in several cases constitute a gas-bearing horizon, is common. Hence, the best and simultaneously the most resourceful natural gas reservoirs are the sediments of submarine fans and deltaic sediments-the natural gas of the largest deposits is accumulated within them. The last stage of sedimentation in the Carpathian Foredeep was the filling of the remaining space with shallow shelf deposits-poorly sorted, without any visible bedding, fine-grained (mainly) clay and mud sediments. These features were not conducive to the formation of hydrocarbon accumulation, yet gas deposits were found in many regions. Sandy mudstones have a significant share in these settlements; there are also thicker sandstone beds [57].

Dzików sandstones are a special case among sediments (including the higher Sarmatian sandstones) of the Carpathian Foredeep [57]. Thus far, they have been found in the area of the Dzików deposit (No. 12/13), at a depth of 850-1000 m (4 lithosomes). Their thickness ranges from 20 to $50 \mathrm{~m}$. This type of Dzików sandstone presents very high porosity-in the range of $15-35 \%$ and permeability of several hundred $\mathrm{mD}$. Daily high-methane gas production is in the range of 720,000-1,000,000 $\mathrm{Nm}^{3}$ (Dzików field). 


\subsection{Hydrocarbon Traps and Gas Migration}

Due to the widespread occurrence of reservoir rocks and the generation of microbial gas in the Miocene sediments [88], the existence of hydrocarbon accumulation is mainly determined by the manner and directions of gas migration and the rules for the formation of trap deposits. Although each of the deposits discovered so far has a large individuality, for most of them some common features can be distinguished, namely, the type of deposit trap and the kind of sealing it [58]. Besides, this is an extremely important issue in the context of further exploration of hydrocarbon deposits. In the Carpathian Foredeep, the decisive impact on the occurrence's incidence, type of gas traps within Miocene deposits, and thus the zonation of natural gas deposits have had: (1) the shape of the basement's top, (2) the compaction of the Miocene deposits above its elevations, (3) the deforming impact of the pressing Carpathians. Among the types of natural gas traps of the Carpathian Foredeep, both structural and stratigraphic can be distinguished.

The most frequent type of structural trap in the Miocene sediments is compactional anticlines. They formed above the basement's elevations during the compaction of sandyclayey rocks. Their sealing is made of impermeable argillaceous schists. Multi-horizon natural gas deposits in compactional anticlines are characterized by different gas-edge and/or bottom water relations, depending on the facies type and lithology of reservoir rocks [58]. In the situation when gas accumulation is found in explicitly insulated, thicker sandy layers, it is possible to identify clear gas-water contact (here more often the edge water) on each of the horizons. Examples of such accumulations are (Figure 6): the Palikówka (No. 41), Jasionka (No. 20), Chałupki Dębniańskie (No. 8) or Jodłówka (No. 23) deposits and the lower horizons of the Żołynia-Leżajsk (No. 67) deposit [58]. In the case of natural gas accumulated within compactional anticlines composed of heterolithic deposits of the basin floor, thin-stratified turbidites of external submarine fan or distal delta turbidites, each of the thin sandy beds has its own gas-water contact. An example would be the lower horizons of the Palikówka deposit (Figure 6). Significant gas resources are located in the zone along the Carpathian Overthrust, which is the seal on the southern side. From the north, natural gas accumulations are limited by the gas-water contour. The deposits of Przemyśl, Tuligłowy (No. 46), Husów-Albigowa-Krasne (No. 18), Raczyna (No. 48), Pilzno (No. 42) and many others can be mentioned here (Figure 6). The third type of structural trap is associated with fault zones-synsedimental longitudinal normal faults (NW-SE direction) and transverse faults (NE-SW direction). According to Karnkowski [89] longitudinal faults could play the role of migration routes for natural gas, while transverse faults might be trap-forming. Documented examples of such traps are known, among others, from the deposits (Figure 6) of Mołodycz (No. 35), Rudka (No. 50), Sarzyna (No. 52), Rokietnica (No. 49), Jarosław (No. 19), Dzików (No. 12/13) [90], Grodzisko Dolne (No. 15), Chałupki Dębniańskie (No. 8) or Żołynia-Leżajsk (No. 67) [58].

Stratigraphic traps in the Carpathian Foredeep are associated with unconforming surfaces (regional and local). The pinching-out trap types caused by the horizontal and the vertical facies changes are rare and occur most often in the topmost part of the Miocene succession. Traps of this type are known, among others, from the Husów (horizons 11 and 12; No. 17) or the Rudka (horizon 12; No. 50) deposits (Figure 6) [58].

During the formation of Miocene deposits, all the conditions necessary for the generation and accumulation of biogenic gas were met: (1) adequate content of organic matter as a source of natural gas; (2) rapid sedimentation of sandy-clayey sediments in the Miocene Sea basin and its cyclicality; (3) synsedimental tectonics and the creation of compact traps (anticlines); (4) the presence of suitable reservoir rocks; (5) low-temperature regime (constant presence of bacteria) [91]. Thus, as the result of the microbial genesis of gas, its composition is dominated by methane. As stated by Kotarba [88] gas migration was a parallel process to its formation. Moreover, compaction and squeezing water from concentrated sediments favored it [89]. Migration paths could have been porous layers of sandy sediments (lateral migration according to the hydrodynamic gradient) and/or discontinuity surfaces in the form of cracks and faults (vertical migration). 


\section{Primarily Thermal Characteristic of Selected Hydrocarbon Reservoirs}

Having learned the general geothermal and petroleum characteristics of the studied region, the area for a more extensive search for the region(s) of hydrocarbons deposits characterized by prospective geothermal parameters has been narrowed using the minimum temperature criterion. According to the Geological and Mining Law [80], (geo)thermal water is called groundwater, which at the outlet from the intake, has a temperature not lower than $20^{\circ} \mathrm{C}$. This condition excluded from the analysis the very first depth interval of the autochthonous Miocene (i.e., $0-500 \mathrm{~m} \mathrm{bsl}$ ), what has already been clarified in the geothermal characteristics of the region (see Section 4). Another adopted assumption is the suitability of thermal water for the potential production of thermal energy-in the case of deep geothermal energy, it is justified when the water reaches values above $40{ }^{\circ} \mathrm{C}$ [92]. As a result of the alternate adopted temperature criterion, the depth range $500-1000 \mathrm{~m}$ bsl was somewhat omitted in further analysis, although it should be realized that its potential could be used in ground heat pump technology [50]. The depth ranges 0-500 $\mathrm{m}$ bsl and 500-1000 m bsl (i.e., interval A where the temperature does not exceed $40{ }^{\circ} \mathrm{C}$ - see Section 4.3) and thus the hydrocarbon deposits located within these formations has been excluded from further considerations. This narrows the research area for a suitable structure(s) to regions within/near the Carpathian Overthrust zone (Figure 8). At the same time, the number of analyzed gas deposits is reduced to 42 .

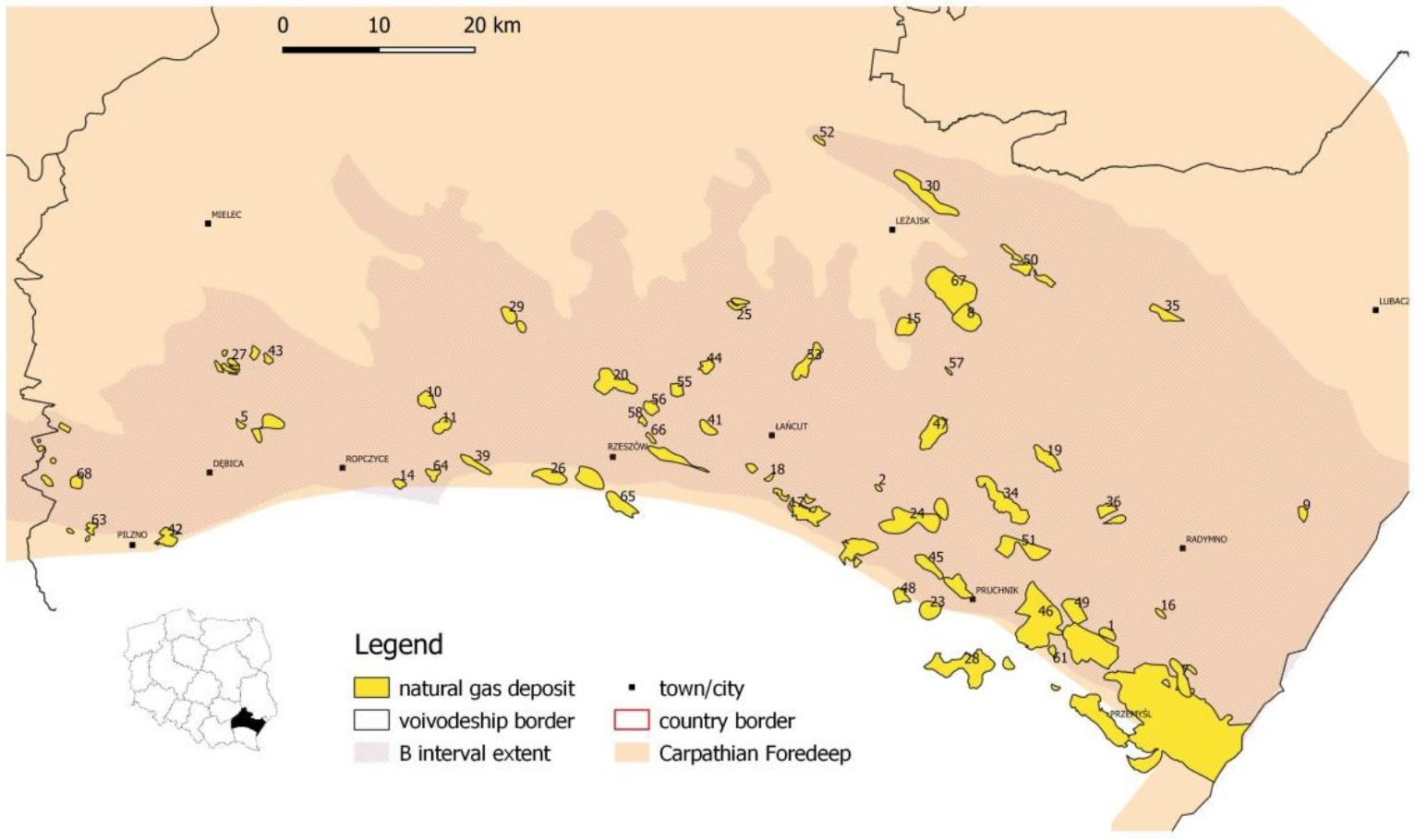

Note: natural gas deposits are numbered according to Table 2. (No. column).

Figure 8. Deposits of natural gas along the Carpathian Overthrust (based on [60-63]).

\subsection{Estimated Temperatures in Selected Deposits}

Using depth data available online (i.e., [60-62]) and GIS software, the depths of deposits and average temperatures for selected natural gas deposits have been estimated. According to the established methodology, the average depths of hydrocarbon deposits were calculated based on Equation (1). Then, having the average depth value, the deposits were assigned to the respective interval. The Jodłówka (natural gas) field (No. 23) is presented as an example for held calculations. 
Based on Equation (1) and data collated in Table 3, the average depth for Jodłówka field (No. 23) was calculated as follows:

$$
\begin{gathered}
x=(1952+3375) / 2 \\
x=2663.5
\end{gathered}
$$

Thereby, the Jodłówka field was assigned to the E depth interval (2500-3500 m), where expected temperatures should exceed $80^{\circ} \mathrm{C}$.

\begin{tabular}{|c|c|c|c|c|c|c|c|c|c|c|c|c|c|c|c|c|c|c|c|}
\hline Name & $\mathrm{J}-4$ & $\mathrm{~J}-6$ & $\mathrm{~J}-18$ & $\mathrm{~J}-22$ & $\mathrm{~J}-25$ & $\mathrm{~J}-14$ & $\mathrm{~J}-15$ & $\mathrm{~J}-13$ & $\mathrm{~J}-17$ & $\mathrm{~J}-10$ & $\mathrm{~J}-27$ & $\mathrm{~J}-19$ & J-9 & $\mathrm{J}-11$ & $\mathrm{~J}-12$ & $\mathrm{~J}-28 \mathrm{~K}$ & $\mathrm{~J}-31$ & $\mathrm{~J}-20$ & $\mathrm{~J}-21$ \\
\hline Depth & 3375 & 2473 & 2537 & 2982 & 2400 & 2600 & 3234 & 2873 & 2661 & 2760 & 1952 & 3085 & 3364 & 2750 & 3305 & 3143 & 2993 & 2800 & 3300 \\
\hline & $\mathbf{h}_{\max }$ & & & & & & & & & & $\mathbf{h}_{\min }$ & & & & & & & & \\
\hline
\end{tabular}

Table 3. The wells throughout the Jodłówka natural gas field (based on [60-62]).

The deepest (hmax) and the shallowest (hmin) wells are marked bold. These indicated depth values were used for calculation with Equation (1).

Most of the natural gas deposits in the analyzed area are located within the 1000-1500 m average depth interval (interval B), where average temperatures do not exceed $40-50{ }^{\circ} \mathrm{C}$ (Figure 9). Deposits with estimated temperatures exceeding these values, in the majority, lie far deeper (i.e., intervals D and E) and closer to the Carpathian Overthrust area. Accordingly, within this area, eleven deposits with an estimated temperature reaching even up to $80 / 90^{\circ} \mathrm{C}$ have been distinguished (Figures 8 and 9), namely, Zalesie (No. 65), Zagorzyce (No. 64), Rączyna (No. 48), Przemyśl (No. 46), Pruchnik-Pantalowice (No. 45), Pilzno Południe (No. 42), Nosówka (No. 38/39), Kielanówka-Rzeszów (No. 26), Jodłówka (No. 23), Gubernia (No. 16) and Buszkowiczki (No. 7). Moreover, a few of those are presented briefly in the following section.

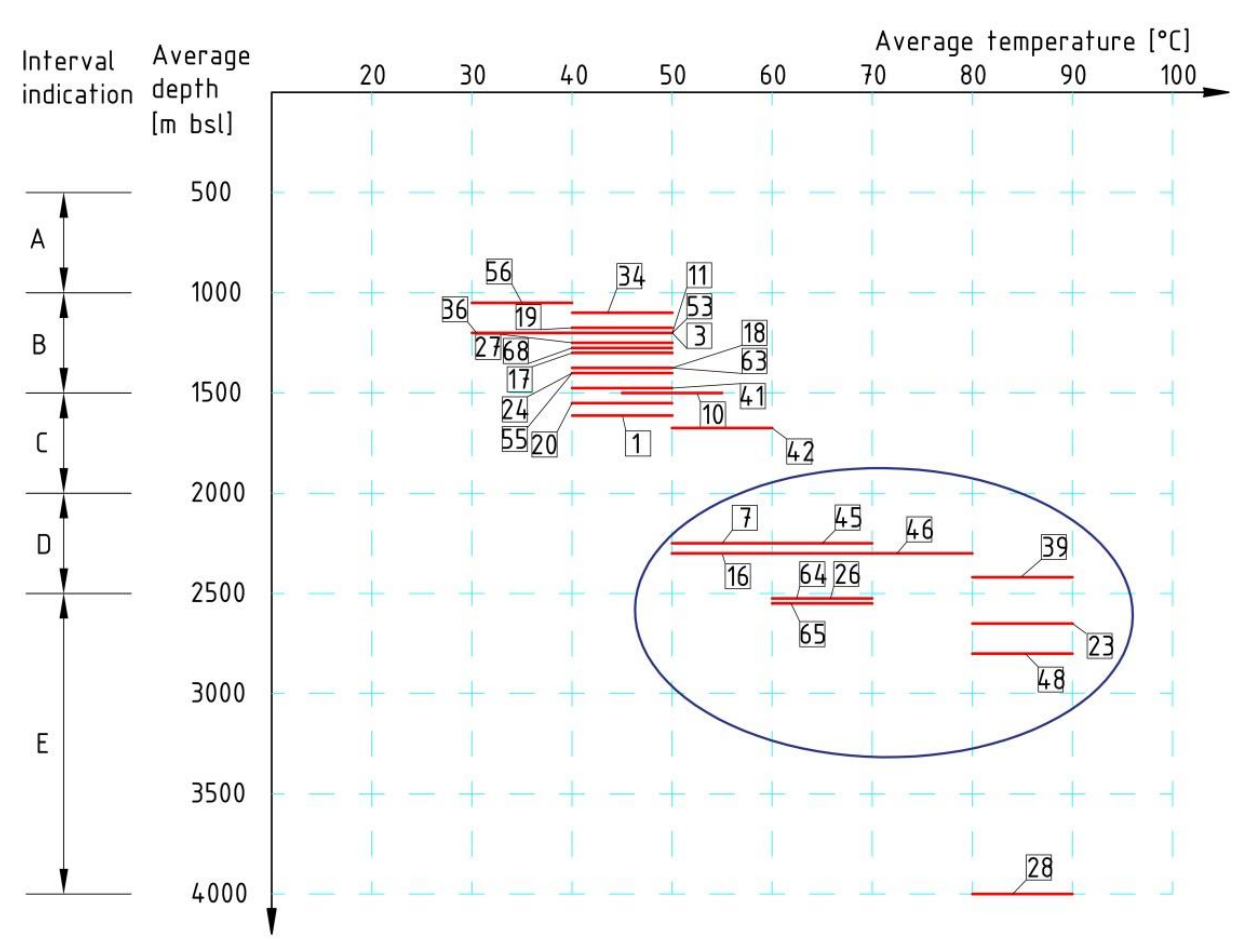

Figure 9. Average depths and temperatures of selected hydrocarbon deposits (based on the [60,61]). Legend: 1-Batycze, 3-Blizna-Ocieka, 7-Buszkowiczki (Przemyśl), 10-Cierpisz, 11-Czarna Sędziszowska, 16-Gubernia, 17-Husów, 18-Husów-Albigowa-Krasne, 19-Jarosław, 20-Jasionka, 23-Jodłówka, 24-Kańczuga, 26-Kielanówka-Rzeszów, 27-Korzeniów, 28-Kramarzówka, 34-Mirocin, 36-Morawsko, 39-Nosówka, 41—Palikówka, 42-Pilzno Południe, 45-Pruchnik-Pantalowice, 46-Przemyśl, 48-Rączyna, 53-Smolarzyny, 55-Stobierna, 56-Terliczka, 63-Wygoda, 64-Zagorzyce, 65-Zalesie, 68-Żukowice. 
At this point, it is also worth emphasizing the fact that due to the large dispersion of the depth of individual boreholes within one deposit (especially in the case of larger ones, such as, e.g., Przemyśl), it would be better/safer to subject individual wellbores to detailed thermal analysis. For instance, the average estimated temperature for the largest of the analyzed oil fields-Przemyśl (No. 46), was estimated as 50-80 ${ }^{\circ} \mathrm{C}$ (Figure 9). However, taking into account specific boreholes, their location and depths, etc., real temperatures can fluctuate to a much greater extent, i.e., in this case, from about $40{ }^{\circ} \mathrm{C}$ to over $80{ }^{\circ} \mathrm{C}$, which can significantly affect potential development options [92] and profitability (energy, financial and social, etc.) of a future geothermal project.

\subsection{Characteristics of a Few Natural Gas Fields}

From among the aforementioned eleven deposits that presented the highest estimated temperatures (Figure 9), several located along the Carpathian Overthrust (Figure 8) have been selected to be presented in detail, namely, Pilzno-Południe (No. 42), KielanówkaRzeszów (No.26), Zalesie (No. 65) Jodłówka (No. 23) and Przemyśl (No. 46). Thus, general characteristics of chosen deposits, some historical and current data on natural gas production, were presented, including information on formation waters if such were publicly available at the time of writing. Additionally, information about the period of validity of the mining concession has also been included.

\subsubsection{Pilzno Południe Field (No. 42)}

The multilevel natural gas field was discovered in 1981 near Pilzno (Figure 8). It covers an area of 487 ha [61]. According to Jawor [93], gas accumulation occurs in six sandstone levels between 18-33 m thick, isolated by claystone layers. The effective porosity of the reservoir rock was set at 20-25\%, and the permeability reaches $1500 \mathrm{mD}$. The deposit rests at a depth of 1606-1773 m (Badenian and Sarmatian) and is located on the top of the anticline, cut transversely with the surface of the Carpathian overthrust (shielding from the southern side) [51]. The current concession for natural gas production is valid till the end of the year 2023 [61].

\subsubsection{Kielanówka-Rzeszów Field (No. 26)}

The deposit of high-methane natural gas in the western periphery of Rzeszów (Figure 8) was discovered in 1978 by drilling four wells. Its area is determined as 838.5 ha [61]. The accumulation of gas has been identified in two separate sandy levels (2259-2350 m; 2600-2650 m) within the sandy-silt-clayey formation of autochthonous Miocene. The Kielanówka-Rzeszów deposit has the form of a flat anticline with a longitudinal axis direction SEE-NWW [51]. Deposit traps are made of fine- and medium-grained, weakly compact sandstones interleaved with thin inserts of silt and claystone. Their thickness is 31.5-43 $\mathrm{m}$ for the first level and 21-40 $\mathrm{m}$ for the second level. Effective thicknesses are smaller and amount to 20-36 m and 5.7-12.5 m, respectively. It is a multilayer deposit with edge water [51]. The average temperature of the deposit is about $67^{\circ} \mathrm{C}$ in all horizons [61]. Nevertheless, since it is a spot metering and the thicknesses of all horizons are different, the given temperature should be taken indicative. The concession for natural gas production is valid till the end of year 2038 .

\subsubsection{Zalesie Field (No. 65)}

The Zalesie deposit (Figure 8; current area of 411.1 ha [61]) was discovered in 1982 in the Upper Badenian, at a depth of 2120-2138 m and 2070-2104 m (Zalesie 2 borehole) [51]. Initial reservoir pressure was equal to $22.66 \mathrm{MPa}$, and discharge varied in the range of $627-1324 \mathrm{Nm}^{3} / \mathrm{min}$ [51]. This deposit is associated with a strongly elevated Miocene structure of SE-SW extent, within which four reservoir levels were separated. Highmethane gas (98-99\% methane, the rest are heavier hydrocarbons: ethane-propane-butane) occurs in sandy deposits. Each horizon presents varying degrees of shale content and has its own gas-water contour. Reservoir rocks have an average thickness of $24.5 \mathrm{~m}$, average 
porosity of $12 \%$ and a permeability of up to $145 \mathrm{mD}$. The water level surrounding the multilayer deposit was assumed at a depth of $2000 \mathrm{~m}$ [51], whereas the bottom water reaches the maximum depth of $2590 \mathrm{~m}$ [61]. Approximate spot-measured temperatures within the field's depth profile (different horizons within the Upper Badenian formation) vary between 57 and $61^{\circ} \mathrm{C}$ [61]. The concession for natural gas production from the Zalesie field is valid until the end of the year 2023.

\subsubsection{Jodłówka Field (No. 23)}

The Jodłówka deposit (Figure 8) was discovered in 1980 at a depth of 2870-2878 $\mathrm{m}$ in the Upper Badenian and Lower Sarmatian formations [51]. It has an area of 265 ha [61]. A gas flow of $81 \mathrm{~m}^{3} / \mathrm{min}$ and a pressure of $232.3 \mathrm{~atm}$. were obtained, which became the basis for the further exploration work. As a result, a multi-layer ( 24 accumulation levels were documented [65] natural gas deposit in the shaly sandy Miocene formation, where a rarely occurring (as for such a small gas field) resource of 1500-1800 million $\mathrm{Nm}^{3} / \mathrm{km}^{2}$ was discovered [65]. According to Borys [65], 25-30\% of the Miocene depth profile, in the center of the deposit, are gas-bearing levels. Their total thickness in the central part of the gas field is about $500 \mathrm{~m}$ [65], and the deposit surface exceeds $3 \mathrm{~km}^{2}$ [64]. The Jodłówka deposit is considered to be a fairly regular anticlinal form limited by a steep wing to the south and shallow synclinal zones from the other directions. Its amplitude, calculated from the synclinic closures to the top, is on average about $40 \mathrm{~m}$ [64]. Lower horizons have greater closure amplitudes, while higher ones are gradually flattened what is characteristic for forms of a compact nature. Within the autochthonous Miocene profile, seven basic sandstone levels were separated (from VI to XII), and those, after appropriate analysis, were divided into further sub-horizons. Moreover, for most of them, separate contours of formation water can be established [64]. Current data [61] indicate that the field is located at the depth between 1840 and $3270 \mathrm{~m}$ and contour of bottom water is set as $1549.9-2742.9 \mathrm{~m}$. The orientative temperature of the deposit varies between 62 and $90{ }^{\circ} \mathrm{C}$ dependent on the horizon, and ipso facto its depth [61]. The concession for natural gas production is valid to December 2042.

\subsubsection{Przemyśl Field (No. 46)}

The Przemyśl gas field (Figure 8) is one of the largest in the country-the area is equal to 10,792.65 ha [61]. It contains the pools of Przemyśl, Jaksmanice, MaćkowiceTuligłowy and Wapowce [63]. In 1958, in the contact zone of the Stebnik Overthrust and the Carpathian flysch with the autochthonous Miocene of the outer zone, a natural gas deposit was discovered in the vicinity of Przemyśl (exactly in Jaksmanice; Figure 8). It occurs in the autochthonous Miocene formations at a depth of 600-900 m (Jaksmanice pool). Deeper gas accumulation levels were discovered in 1962-1990 (simultaneously expanding the exploration area): the Maćkowice pool 900-1250 m, the Przemyśl pool 1400-1600 m. The deposits mentioned above constitute 3 main packages of productive levels with slightly different characteristics - the effect of the relatively complicated geological structure of the gas field. Generally speaking, the deposit belongs to the type of multilayer deposits (over 30 gas-bearing levels) occurring in the zone of regional elevation of Miocene formations toward the Carpathian Overthrust [51]. The deposit is lithologically shielded from the surface with a series of clay and shale Sarmatian deposits, while on the southern side by Stebnik and Carpathian Overthrusts. The Jaksmanice pool is made up of a large number of thin sandy layers saturated with gas, each with a separate contour of edge water. The average effective porosity of sandy reservoirs is about $19 \%$. The content of bound water in the pores is the highest here and ranges from $19.5 \%$ to $41.4 \%$, obtaining values getting smaller along with the depth and increase of grains' diameter in sandstones. The effective thickness of the Jaksmanice deposit is $580 \mathrm{~m}$ and the permeability ranges from 3-243.8 mD. High-methane gas (methane 95.4\%) is extracted with a small admixture of heavier hydrocarbons and nitrogen $(3.8 \%)$. The edge waters of specific horizons are of pressing character. They are medium mineralized (TDS-24.95 g/ $\mathrm{dm}^{3}$ ), calcium chloride 
type (according to Sulin classification), with a density of $1.03 \mathrm{~g} / \mathrm{cm}^{3}$. The Maćkowice pool $(900-1250 \mathrm{~m}$ ) belongs to the multilayer deposit type. There are two main sandy levels at a depth of 958-1090 m and 1000-1104 m. The effective thickness of the sandstone saturated with high-methane gas amounts to $28 \mathrm{~m}$. The average effective porosity was determined at $17-19.7 \%$, and bound water fills $11 \%$ of the pore space. Waters present in the deposit are of the chloride-calcium type. Mineralization varies depending on the well being analyzed and is a maximum of $25.43 \mathrm{~g} / \mathrm{dm}^{3}$ (Jaksmanice- 23 well). On the other hand, in the Jaksmanice- 28 borehole, weakly mineralized acid-carbonate-sodium brine was encountered [51]. The deepest gas-bearing levels with high efficiency were named the Przemyśl pool. It is a multilayer deposit of the compact type-it occurs in a large, radiated anticline structure, cut off from the south with the overthrust of the Carpathians and the Stebnik unit [51]. The effective thickness of gas-bearing levels ranges between $5 \mathrm{~m}$ and $22 \mathrm{~m}$. Porosity reaches $32 \%$ in higher levels; in others, it oscillates between $9.5-12.5 \%$. The amount of water bound in the pore space is $6-18 \%$, and the permeability reaches around $916 \mathrm{mD}$. The characteristics of individual parameters of the Przemyśl natural gas deposit depending on the reservoir level are summarized in Table 4 . The sand volume of individual gas-bearing levels decreases in the south-east direction, while it increases in the west direction.

Table 4. Characteristic of Przemyśl natural gas field (based on [51]).

\begin{tabular}{cccc}
\hline \multirow{2}{*}{ Parameter } & \multicolumn{3}{c}{ Horizons } \\
\cline { 2 - 4 } & I & II & III \\
\hline Reservoir rock & & Sandstone/Lower Sarmatian \\
\hline Relative depth $[\mathrm{m}]$ & 1965 & 1682 & 1731 \\
\hline Absolute depth $[\mathrm{m}]$ & -1360 & -1483 & -1532 \\
\hline Gas-water contact $[\mathrm{m}$ asl] & -1400 & -1491 & -1551 \\
\hline Porosity $[\%]$ & 21.2 & 9.5 & 12.5 \\
\hline Permeability $[\mathrm{mD}]$ & $10-257$ & $0-342$ & $0-916$ \\
\hline Bound water $[\%]$ & 6.2 & 9.9 & 18.2 \\
\hline Reservoir pressure $[\mathrm{MPa}]$ & 16.7 & 18.0 & 18.7 \\
\hline Well-head pressure $[\mathrm{MPa}]$ & 14.5 & 15.2 & 232 \\
\hline Initial productivity $\left[\mathrm{Nm}{ }^{3} / \mathrm{min}\right]$ & 622 & 57.6 & \\
\hline
\end{tabular}

By 2017, 64.1 billion cubic meters of natural gas and 61.3 thousand tons of formation water were extracted from the Przemyśl field, using over 300 wells [94]. However, the present concession for natural gas production is valid till the end of the year 2037. Natural gas from the Przemyśl pool has high methane content, whereas the brines taken from the edge and bottom water zone indicate considerable variation $[51,66]$ and are of completely different characteristics from those of the Jaksmanice pool. Most of them are acid-carbonsodium brines (according to Sulin classification), with mineralization from $20-25 \mathrm{~g} / \mathrm{dm}^{3}$. The measured temperature in the field reaches up even $82{ }^{\circ} \mathrm{C}$ [61], however it changes in line with local geothermal gradient.

\section{Potential Hazards Connected to the Geothermal Energy Utilization in the Studied Area}

Besides, geothermal energy is considered as a clean and sustainable source of renewable energy - utilization is environmentally friendly and causes hardly any hazards to the natural environment [95] — there are always potential hazards and/or problems that should be addressed.

In the case of natural environment protection, dependent on the kind of geothermal utilization, different perils can occur during the utilization of geothermal energy. Potential emissions of pollutants $\left(\mathrm{CO}_{2}, \mathrm{SO}_{2}, \mathrm{NO}_{\mathrm{x}}\right.$, particulate matter) into the atmosphere might 
occur. However, as stated by Tester [96], this problem is related mainly to the production of electricity in high-temperature geothermal fields and pollutants are of trace amounts in comparison to conventional power plants. Thereby, in the case of the Carpathian Foredeep, the possible emission of pollutants into the atmosphere might be neglected. Another hazard is connected to water and ground environments, which are in danger primarily due to the drilling works, nonetheless, during the (misconducted) exploitation of geothermal energy the negative effect might occur. Among the problems, one can distinguish possible contamination of groundwater [97], geothermal fluid reduction/exhaustion and land deformations [98] or cooling the geothermal water/rock formation down and risk of the so-called cold front breakthrough. These problems might occur anywhere, as they are connected to inappropriate management (exploitation/injection processes) of geothermal resources. The risk of its occurrence within the studied area cannot be evaluated at that time. The negative impact on the landscape and acoustic climate might occur as well, but usually, it is the most oppressive during the drilling stage [97].

While considering the utilization of geothermal energy, one important issue should be kept in mind-there is no justification for leading any geothermal project if there is no sufficient recipient in proximity. The commodity, heat in the case of geothermal energy within the analyzed area, cannot be stored without conversion to another type of energy as it degrades (opposite to hydrocarbons). Thus, to have a commercially viable project, the market needs to be in the close vicinity. That means greater proximity to people, and thereby requires greater environmental, formal as well as social concerns. If one wants to use the existing oil and gas wells, a problem related to their technical condition may arise, preventing its reconstruction (preceded by appropriate tests), and consequently, re-use for geothermal purposes [13,50]. Additionally, aggressive brines might constitute the problem within the analyzed area as geothermal waters contain elements, such as $\mathrm{CO}_{2}$ or $\mathrm{H}_{2} \mathrm{~S}$, etc. [50]. The corrosive activity depends on the degree of mineralization (TDS), mainly the content of anions: $\mathrm{Cl}^{-}, \mathrm{SO}_{4}{ }^{2-}, \mathrm{CO}_{3}{ }^{-}, \mathrm{CO}_{3}{ }^{2-}$. In turn, the corrosion rate of metals in geothermal waters depends, among others, on physical and chemical conditions, mainly temperature, as well as type and speed of flow [50]. As these are only theoretical considerations, all these problems should be further re-identified and reassessed for specific wells intended for geothermal purposes within the analyzed area.

\section{Discussion}

The research area within the Polish part of Carpathian Foredeep (Figure 1) is relatively well-recognized, due to the production of hydrocarbons that have lasted many years (over 3000 boreholes; Figure 2). It also belongs to the second biggest petroleum province in Poland-the Lesser Poland or Carpathian Province [37]. Generally, the autochthonous Miocene of the Eastern part of the Carpathian Foothills is the sequence of sandstones, siltstones and claystones (Figure 3), that thickness total more than $3 \mathrm{~km}$ in the Southern part (Figure 4). These are the Badenian-Sarmatian age formations [51], originating mainly from the erosion of the folded Carpathian Flysch [67]. The autochthonous Miocene formations of the analyzed area constitute accumulation horizons, mainly for natural gas (69 deposits; Table 2, Figure 6), although small reserves of crude oil have also been found here (6 deposits; Table 2, Figure 6). The paper mainly focused on natural gas deposits as frequently occurred and prospective structures in the context of the possibility of a re-use after the end of hydrocarbon production. These deposits present a stacked-pool, sporadically massive type. The reservoir rock consists mainly of sandstones, which are sealed with siltstone/claystone layers or tectonically shielded. As the authors cited in the text emphasized $[51,66]$ formation water is a brine of different types and physico-chemical parameters (dependent on deposit and depth of its deposition). It accompanies not only entire deposits, but also individual gasbearing horizons. In the case of geothermal, the autochthonous Miocene of the presented part of Carpathian Foredeep is a prospective reservoir in terms of the potential use of geothermal water and energy [50]. Favorable conditions occur locally, depending on, among others, geological settings and the depth of selected deposit deposition. Along 
with the depth, reservoir, hydrogeological as well as thermal parameters (Table 5) are changing, and the encountered conditions are strictly dependent on the location and depth of the structure or precisely the borehole(s) chosen for analysis. Generally, the deeper one gets, the higher temperature is expected to occur (Figures 5 and 9), however, the selected boreholes' capacity declines (or is already low) (Table 1). Water-bearing horizons are significant in thickness, reaching up to $350 \mathrm{~m}$ (interval A). Mineralization hits maximum values of approx. $175 \mathrm{~g} / \mathrm{dm}^{3}$ in interval D. Petrophysical and hydrogeological parameters are similar if it comes to values throughout individual intervals (Table 5). However, it can be noticed that theoretically, the most favorable conditions occur at an interval of the depth of 500-1000 m bsl; nonetheless, the estimated temperature is not high enough for the efficient management of geothermal energy. In this case, it seems most reasonable to consider deeper-located reservoir structures that present higher estimated temperatures.

Table 5. Summary of geothermal parameters within depth profile of autochthonous Miocene (based on [50]).

\begin{tabular}{|c|c|c|c|c|c|c|c|c|c|}
\hline $\begin{array}{l}\text { Interval } \\
\text { Signa- } \\
\text { ture }\end{array}$ & $\begin{array}{l}\text { Depth } \\
\text { Interval }\end{array}$ & Temperature & $\begin{array}{c}\text { Water- } \\
\text { Bearing } \\
\text { Horizon }\end{array}$ & $\begin{array}{l}\text { Boreholes' } \\
\text { Capacities }\end{array}$ & TDS & $\begin{array}{l}\text { Hydraulic } \\
\text { Conductivity }\end{array}$ & $\begin{array}{l}\text { Effective } \\
\text { Porosity }\end{array}$ & Permeability & $\begin{array}{c}\text { Shale } \\
\text { Volume }\end{array}$ \\
\hline unit & [m bsl] & {$\left[{ }^{\circ} \mathrm{C}\right]$} & [m] & {$\left[\mathrm{m}^{3} / \mathrm{h}\right]$} & {$\left[\mathrm{g} / \mathrm{dm}^{3}\right]$} & {$\left[\mathrm{m}^{2} / \mathrm{s} \times 10^{-5}\right]$} & [\%] & [mD] & [\%] \\
\hline $\mathrm{A}$ & 500-1000 & $20-40$ & up to 350 & up to 120 & up to 75 & up to 60 & up to 22.5 & up to 100 & $20-45$ \\
\hline B & $1000-1500$ & $30-50$ & up to 150 & up to 50 & up to 100 & up to 18 & up to 20 & up to 100 & $25-45$ \\
\hline C & 1500-2000 & $40-60$ & up to 125 & up to 40 & up to 125 & up to 13 & up to 17.5 & up to 100 & $30-45$ \\
\hline $\mathrm{D}$ & $2000-2500$ & $50-70$ & up to 75 & up to 30 & $25-175$ & up to 11 & up to 17.5 & up to 100 & $25-45$ \\
\hline $\mathrm{E}$ & $2500-3500$ & $80-100$ & up to 200 & up to 30 & $50-150$ & up to 17 & up to 12.5 & up to 30 & $25-45$ \\
\hline
\end{tabular}

The analyzed area of Carpathian Foredeep is well endowed with boreholes (abandoned or still operating, Figure 2), which translates into high possibility in terms of their potential reconstruction (although this depends directly on the technical condition of the hole and requires a pre-analysis/test) and destination for geothermal purposes. Theoretically, many of them could be suitable for the exploitation and injection of water after performing appropriate reconstruction operations $[13,50]$ or for the implementation of different geothermal technology [28,35]. This is also a big advantage because, in the case of any geothermal investment, the drilling stage is the largest financial burden (even up to $80 \%$ [19]) - the deeper the borehole is, the more expensive the projected investment. Drilling costs are estimated between 12-23 million PLN (i.e., around 2.7-5.2 million EUR [99], for holes with a depth of 1000 and $2500 \mathrm{~m}$, respectively [50]. However, as the estimated cost calculations of the works related to the potential reconstruction of the $2164 \mathrm{~m}$ deep wellbore located within the Przemyśl gas field (Figure 8; No. 46) show, the re-use of the well may bring savings of several million [50]. Nonetheless, the final costs depend on the general technical condition of the borehole, with particular emphasis on the tightness of casing pipes, the repair of which can significantly increase the costs associated with reconstruction (rendering the process even more expensive than drilling the brand new hole). That is the main and most important reason for leading previous tests on the petroleum well selected for being re-used. The most desirable way to use geothermal energy around the world is to produce electricity; nonetheless, in the case of the Carpathian Foredeep, it seems rather unlikely, due to the temperatures being too low and/or potential capacities of boreholes [52,53]. Nevertheless, there are great possibilities for geothermal energy management in the recreation and balneological sector (depending on the physico-chemical parameters of water), agriculture, agribusiness, industry, etc., and with appropriate sociodemographic conditions directly in the district heating sector $[45,46,50]$ or using the heat pump technology [50]. However, in order to improve the efficiency of possible geothermal installation operations, the cascade system is recommended. After the energy transfer in the heating system, the optimum geothermal development might be developed, like in a cascade of a few successive elements, e.g., geothermal swimming pool, warming of greenhouses, wood drying, and other uses up to the production of cosmetics or food. 


\section{Conclusions}

Considering geological and reservoir issues, this analysis also proves that the subject of using AOGWs for geothermal purposes is being considered by scientists around the world (incl. [16]). Solutions that are supposed to enable the efficient, economically justified and environmentally friendly use of geothermal energy are sought and tested within petroleum fields, worldwide. The use of AOGWs creates inherent opportunities to focus on hydrocarbons structures as potential reservoirs of geothermal energy (water and/or heat). Being endowed with numerous petroleum wells (in various current development states and technical conditions), the research area is prospective to become the distinguishable (both in Poland and around the globe) geothermal region. The most promising areas occur near the area of the Carpathian Overthrust-natural gas deposits (and deep boreholes) are abundant there (Figure 8), and located deeper (up to $3500 \mathrm{~m}$ ), so estimated temperatures can reach locally even $100^{\circ} \mathrm{C}$. Out of the most promising regions the following ones might be distinguished (Table 2; Figures 8 and 9): Buszkowiczki (No. 7), Gubernia (No. 16), Jodłówka (No. 23), Kielanówka-Rzeszów (No. 26), Nosówka (No. 38/39), Pilzno-Południe (No. 42), Pruchnik-Pantalowice (No. 45), Przemyśl (No. 46), Rączyna (No. 48), Zagorzyce (No. 64) and Zalesie (No. 65). However, to indicate one/several specific deposits that might be highly prospective to be used for geothermal energy extraction, further and detailed analysis should be carried out. Moreover, based on detailed borehole data, focusing not only on the deposit as a whole, but on individual boreholes.

Summing up, it can be easily noted that the occurrence of hydrocarbon deposits within the analyzed region of the Carpathian Foredeep is determined by local geological settings. What is more, geology has a strong influence on the condition and quality of main geothermal parameters, such as temperature, the occurrence of aquifers, physical and chemical properties of water, porosity and permeability of rocks, etc. However, due to the specific geological structure of the studied area, geothermal conditions within one deposit may differ significantly, both within vertical and horizontal profiles. Yet, due to their form and overall general characteristics, natural gas deposits in the eastern part of the Carpathian Foredeep can be an excellent (sufficient for primarily heat production) geothermal pool. Moreover, the presence of reservoir waters with specific physicochemical parameters creates potential opportunities for their use as an energy carrier by the implementation of the appropriate technology. Since the analyzed area is a petroleum province, there are any hundreds of wells in different technological and development states, which gives a high probability of successful reconstruction and the re-use of AOGWs for geothermal purposes, and thereby generate economic and ecological profits. The next important factor for any geothermal project is proximity to potential recipients and should be considered as a key factor while choosing the definite location of the potential geothermal system based on hydrocarbon well. It needs to be highlighted that the determination of a specific hydrocarbon structure(s)/region(s) and its geothermal potential requires further profound analysis that should be carried out in the context of the entire deposit, as well as individual wells.

Author Contributions: Conceptualization, A.C. and A.S.; methodology, A.C., A.S.; software, A.C.; validation, A.C., A.S., B.T.; formal analysis, B.T.; resources, A.S., A.C., B.T.; data curation, A.C., A.S.; writing-original draft preparation, A.C.; writing-review and editing, A.C., A.S., B.T.; visualization, A.C.; supervision, A.S., B.T.; project administration, A.S.; funding acquisition, A.S., B.T. All authors have read and agreed to the published version of the manuscript.

Funding: This research was funded by AGH University of Science and Technology, grant number 16.16.140.315.

Institutional Review Board Statement: Not applicable.

Informed Consent Statement: Not applicable.

Data Availability Statement: Publicly available datasets were analyzed in this study. This data can be found here: The Polish Geological Institute-National Research Institute, i.e., Central Geological 
Database Download Manager [http:/ / dm.pgi.gov.pl/] (accessed on 20 June 2020) and MIDAS System [http:/ / geoportal.pgi.gov.pl/midas-web] (accessed on 28 June 2020).

Conflicts of Interest: The authors declare no conflict of interest.

\section{References}

1. Bundschuh, J.; Chen, G.; Tomaszewska, B.; Ghaffour, N.; Mushtaq, S.; Hamawand, I.; Reardon-Smith, K.; Maraseni, T.; Banhazi, T.; Mahmoudi, H.; et al. Solar, wind and geothermal energy application in agriculture: Back to the future? In Geothermal, Wind and Solar Energy Applications in Agriculture and Aquaculture (Sustainable Energy Developments); Bundschuh, J., Chen, G., Chandrasekharam, D., Piechocki, J., Eds.; CRC Press, Taylor \& Francis Group: London, UK, 2017; pp. 1-32.

2. Liu, X.; Falcone, G.; Alimonti, C. A systematic study of harnessing low-temperature geothermal energy from oil and gas reservoirs. Energy 2018, 142, 346-355. [CrossRef]

3. Hajto, M.; Sowiżdżał, A. A global assessment of geothermal resources. In Geothermal Water Management (Sustainable Water Developments: Resources, Management, Treatment, Efficiency and Reuse); Bundschuh, J., Tomaszewska, B., Eds.; CRC Press, Taylor \& Francis Group: London, UK, 2018; pp. 3-30.

4. Tomaszewska, B.; Pajak, L.; Bundschuh, J.; Bujakowski, W. Low-enthalpy geothermal energy as a source of energy and integrated freshwater production in inland areas: Technological and economic feasibility. Desalination 2018, 435, 35-44. [CrossRef]

5. Pajakk, L.; Tomaszewska, B.; Bujakowski, W.; Bielec, B.; Dendys, M. Review of the low-enthalpy Lower Cretaceous geothermal energy resources in Poland as an environmentally friendly source of heat for urban district heating systems. Energies 2020, 13, 1302. [CrossRef]

6. Ghaffour, N.; Bundschuh, J.; Mahmoudi, H.; Goosen, M.F.A. Renewable energy-driven desalination technologies: A comprehensive review on challenges and potential applications of integrated systems. Desalination 2015, 356, 94-114. [CrossRef]

7. Gude, V.G. Geothermal source potential for water desalination-Current status and future perspective. Renew. Sust. Energy Rev. 2016, 57, 1038-1065. [CrossRef]

8. Lund, J.W.; Boyd, T.L. Direct utilization of geothermal energy 2015 worldwide review. Geothermics 2015, 60, 66-93. [CrossRef]

9. Bertani, R. Geothermal power generation in the world 2010-2014 update report. Geothermics 2016, 60, 31-43. [CrossRef]

10. Świerszcz, K.; Osial, M. Energy poverty and geothermal resources in the county's energy security strategy. In Contemporary Management and Security Problems; Runiewicz, R., Żylińska, J., Szczerbak, M., Przychocka, I., Gawkowski, K., Eds.; University of Technology and Economics in Warsaw: Warsaw, Poland, 2019; pp. 260-285.

11. Kaczmarczyk, M.; Sowiżdżał, A.; Tomaszewska, B. Energetic and Environmental Aspects of Individual Heat Generation for Sustainable Development at a Local Scale-A Case Study from Poland. Energies 2020, 13, 454. [CrossRef]

12. Mackiewicz, M. Energia geotermalna, a bezpieczeństwo energetyczne Polski-ujęcie prawne. In Bezpieczeństwo energetyczne, rynki surowców i energii-teraźniejszość i przyszłość; Kwiatkiewicz, P., Ed.; FNCE: Poznań, Poland, 2014; pp. $289-305$.

13. Bujakowski, W.; Bielec, B.; Miecznik, M.; Pają, L. Reconstruction of geothermal boreholes in Poland. Geotherm. Energy 2020, 8, 10. [CrossRef]

14. Sowiżdżał, A.; Tomaszewska, B.; Chmielowska, A. Development of the Polish geothermal sector in the light of current possibilities of financial support for a geothermal investment. E3S Web Conf. 2019, 86, 00034. [CrossRef]

15. Caulk, R.A.; Tomac, I. Reuse of abandoned oil and gas wells for geothermal energy production. Renew. Energy 2017, 112, 388-397. [CrossRef]

16. Nian, Y.L.; Cheng, W.L. Insight into geothermal utilization of abandoned oil and gas wells. Renew. Sust. Energy Rev. 2018, 87, 44-60. [CrossRef]

17. Bundschuh, J.; Ghaffour, N.; Mahmoudi, H.; Goosen, M.; Mushtaq, S.; Hoinkis, J. Low-cost low-enthalpy geothermal heat for freshwater production: Innovative applications using thermal desalination processes. Renew. Sust. Energy Rev. 2015, 43, 196-206. [CrossRef]

18. Tomaszewska, B.; Bundschuh, J.; Pająk, L.; Dendys, M.; Quezada, V.D.; Bodzek, M.; Armienta, M.A.; Muñoz, M.O.; Kasztelewicz, A. Use of low-enthalpy and waste geothermal energy sources to solve arsenic problems in freshwater production in selected regions of Latin America using a process membrane distillation-Research into model solutions. Sci. Total Environ. 2020, 714, 136853. [CrossRef]

19. $\mathrm{Bu}, \mathrm{X} . ; \mathrm{Ma}, \mathrm{W} . ; \mathrm{Li}, \mathrm{H}$. Geothermal energy production utilizing abandoned oil and gas wells. Renew. Energy 2012, 41, 80-85. [CrossRef]

20. Thiessen, R.J.; Achari, G. Abandoned oil and gas well site environmental risk estimation. Toxicol. Environ. Chem. 2016, 99, 1170-1192. [CrossRef]

21. Cheng, W.L.; Li, T.T.; Nian, Y.L.; Wang, C.L. Studies on geothermal power generation using abandoned oil wells. Energy 2013, 59, 248-254. [CrossRef]

22. Templeton, J.D.; Ghoreishi-Madiseh, S.A.; Hassani, F.; Al-Khawaja, M.J. Abandoned petroleum wells as sustainable source of geothermal energy. Energy 2014, 70, 366-373. [CrossRef]

23. Davis, A.P.; Michaelides, E.E. Geothermal power production from abandoned oil wells. Energy 2009, 34, 866-872. [CrossRef]

24. Noorollahi, Y.; Pourarshad, M.; Jalilinasrabady, S.; Yousefi, H. Numerical simulation of power production from abandoned oil wells in Ahwaz oil field in southern Iran. Geothermics 2015, 55, 16-23. [CrossRef] 
25. Wight, N.M.; Bennett, N.S. Geothermal energy from abandoned oil and gas wells using water in combination with a close wellbore. Appl. Therm. Eng. 2015, 89, 908-915. [CrossRef]

26. Nian, Y.L.; Cheng, W.L. Evaluation of geothermal heating from abandoned oil wells. Energy 2018, 142, 592-607. [CrossRef]

27. Noorollahi, Y.; Taghipoor, S.; Sajadi, B. Geothermal sea water desalination system (GSWDS) using abandoned oil/gas wells. Geothermics 2017, 67, 66-75. [CrossRef]

28. Tyszer, M.; Chmielowska, A.; Tomaszewska, B. Initial recognition of the possibilities of use abandoned oil and gas wells to desalinate produced water. E3S Web Conf. 2020, 154, 05002. [CrossRef]

29. Templeton, J.D.; Hassani, F.; Ghoreishi-Madiseh, S.A. Study on effective solar energy storage using a double pipe geothermal. Renew. Energy 2016, 86, 173-181. [CrossRef]

30. Bujakowski, W. Rekonstrukcja otworu Mszczonów IG-1 na potrzeby eksploatacji złoża geotermalnego do systemu grzewczego. In Wybrane problemy wykorzystania geotermii-I. Studia Rozprawy Monografie nr 76; Bujakowski, W., Ed.; MEERI PAS: Kraków, Poland, 2000; pp. 63-107.

31. Bujakowski, W. Reconstruction of the MszczonówIG-1 well against the background of other selected geothermal wells' reconstruction projects. Geol. Explor. Technol. Geotherm. Energy Sustain. Dev. 2015, 1, 17-34.

32. Bielec, B.; Balcer, M. The long-term monitoring of the thermal water reservoir exploitation, technical condition of the Mszczonów IG-1 wellborne and production zone. Geol. Explor. Technol. Geotherm. Energy Sustain. Dev. 2015, 1, 37-57.

33. Cheng, W.L.; Liu, J.; Nian, Y.L.; Wang, C.L. Enhancing geothermal power generation from abandoned oil wells with thermal reservoir. Energy 2016, 109, 537-545. [CrossRef]

34. Sapińska-Śliwa, A.; Rosen, M.A.; Gonet, A.; Śliwa, T. Deep Borehole Heat Exchangers-A Conceptual Review. In Proceedings of the World Geothermal Congress 2015, Melbourne, Australia, 19-25 April 2015.

35. Chmielowska, A.; Tomaszewska, B.; Sowiżdżał, A. The Utilization of Abandoned Petroleum Wells in Geothermal Energy Sector. Worldwide Trends and Experience. E3S Web Conf. 2020, 154, 05004. [CrossRef]

36. Cheng, W.L.; Li, T.T.; Nian, Y.L.; Xie, K. Evaluation of working fluids for geothermal power generation from abandoned oil wells. Appl. Energy 2014, 118, 238-245. [CrossRef]

37. Polish Geological Institute-National Research Institute. Oil and Gas in Poland-New Opportunities. Available online: https: / /infolupki.pgi.gov.pl/sites/default/files/czytelnia_pliki/folder_na_bruksele.pdf (accessed on 20 May 2020).

38. Górecki, W.; Sowiżdżał, A.; Hajto, M.; Wachowicz-Pyzik, A. Atlases of geothermal waters and energy resources in Poland. Environ. Earth Sci. 2015, 74, 7487-7495. [CrossRef]

39. Wójcicki, W.; Sowiżdżał, A.; Bujakowski, W. Ocena potencjatu, bilansu cieplnego i perspektywicznych struktur geologicznych dla potrzeb zamkniętych systemów geotermicznych (Hot Dry Rocks) w Polsce; Ministry of the Environment: Warszawa/Kraków, Poland, 2013.

40. Bujakowski, W.; Tomaszewska, B. Atlas of the Possible Use of Geothermal Waters for Combined Production of Electricity and Heat Using Binary Systems in Poland; MEERI PAS: Kraków, Poland, 2014.

41. Miecznik, M.; Sowiżdżał, A.; Tomaszewska, B.; Pajak, L. Modeling geothermal conditions in part of the Szczecin Trough-The Chociwel area. GEOLOGOS 2015, 21, 187-196. [CrossRef]

42. Wachowicz-Pyzik, A.; Sowiżdżał, A.; Pająk, L.; Ziółkowski, P.; Badur, J. Assessment of the effective variants leading to higher efficiency for the geothermal doublet, using numerical analysis-case study from Poland (Szczecin Trough). Energies 2020, 13, 2174. [CrossRef]

43. Sowiżdżał, A.; Chmielowska, A.; Tomaszewska, B.; Operacz, A.; Chowaniec, J. Could geothermal water and energy use improve living conditions? Environmental effects from Poland. Arch. Environ. Prot. 2019, 45, 109-118. [CrossRef]

44. Maćkowski, T.; Sowiżdżał, A.; Wachowicz-Pyzik, A. Seismic methods in geothermal water resource exploration: Case study from Łódź Trough, central part of Poland. Geofluids 2019, 3052806, 1-11. [CrossRef]

45. Kepińska, B. A review of geothermal energy uses in Poland in 2016-2018. Geol. Explor. Technol. Geotherm. Energy Sustain. Dev. 2018, 1, 11-28.

46. Sowiżdżał, A. Geothermal energy resources in Poland-Overview of the current state of knowledge. Renew. Sust. Energy Rev. 2018, 82, 4020-4027. [CrossRef]

47. Kondracki, J. Geografia Regionalna Polski; PWN: Warszawa, Poland, 2009.

48. Sowiżdżał, K.; Słoczyński, T.; Sowiżdżał, A.; Papiernik, B.; Machowski, G. Miocene biogas generation system in the Carpathian Foredeep (SE Poland): A basin modeling study to assess the potential of unconventional mudstone reservoirs. Energies 2020, 13, 1838. [CrossRef]

49. Oszczypko, N. Development of the Polish sector of the Carpathian Foredeep. Pol. Geol. Rev. 2006, 54, $396-403$.

50. Górecki, W. Geothermal Atlas of the Carpathian Foredeep; KSE AGH-UST: Kraków, Poland, 2012.

51. Karnkowski, P. Złoża gazu ziemnego i ropy naftowej w Polsce. Tom 2. Karpaty i zapadlisko przedkarapackie; WNT: Kraków, Poland, 1993.

52. Sowiżdżał, A. Characterization of geothermal reservoirs parameters in Polish part of Carpathian Foredeep. Carpath J. Earth Environ. 2015, 10, 237-246.

53. Sowiżdżał, A.; Górecki, W. Possibilities of geothermal energy utilization in the Carpathian Foredeep. Geol. Explor. Technol. Geotherm. Energy Sustain. Dev. 2013, 52, 59-73.

54. Sowiżdżał, A.; Jasnos, J. The analysis of chemical composition of groundwaters from Miocene formations in the Carpathians Foredeep from the point of view therapeutical properties. Geol. Explor. Technol. Geotherm. Energy Sustain. Dev. 2011, 1-2, 365-376. 
55. Chowaniec, J. Wody podziemne wschodniej części Karpat i zapadliska przedkarpackiego oraz ich ochrona. In Poszukiwanie węglowodorów jako źródło postępu w rozpoznawaniu budowy geologicznej Karpat, Zapadliska Przedkarpackiego i ich podłoża; Dziadzio, P., Uchman, A., Eds.; Polish Geological Institute: Iwonicz-Zdrój, Poland, 2004; pp. 79-91.

56. Piesik-Buś, W.; Miziołek, M. Bilans stanu zasobów gazu ziemnego na przykładzie złóż zapadliska przedkarpackiego. Naft. Gaz 2016, 11, 945-952. [CrossRef]

57. Myśliwiec, M. The Miocene reservoir rocks of the Carpathian Foredeep. Pol. Geol. Rev. 2004, 52, 581-592.

58. Myśliwiec, M. Traps for gas accumulations and the resulting zonation of the gas fields in the Miocene strata of the eastern part of the Carpathian Foredeep (SE Poland). Pol. Geol. Rev. 2004, 52, 657-664.

59. Szuflicki, M.; Malon, A.; Tymiński, M. Bilans zasobów złóż kopalin w Polsce wg stanu na 31/12/2018; Polish Geological InstituteNational Research Institute: Warszawa, Poland, 2019.

60. Central Geological Database. Download Manager. Boreholes. Mineral Resources-Mineral Raw Materials Deposits. Mineral Resources-Concessions-Prospecting and Exploration of Hydrocarbons Fields. Available online: http://dm.pgi.gov.pl/ (accessed on 20 June 2020).

61. Polish Geological Institute-National Research Institute. Mineral Deposits. Available online: http://geoportal.pgi.gov.pl/midasweb/pages/index.jsf?conversationContext=3 (accessed on 28 June 2020).

62. The Head Office of Geodesy and Cartography. View Services (WMS and WMTS). Available online: https:/ / www.geoportal.gov. $\mathrm{pl} /$ uslugi/usluga-przegladania-wms (accessed on 20 June 2020).

63. The Head Office of Geodesy and Cartography. Map of the Distribution of Crude Oil and Natural Gas Deposits in Poland. Available online: http://geoportal.pgi.gov.pl/css/surowce/images/2013/mapy/large/large_7.jpg (accessed on 10 May 2020).

64. Myśliwiec, M. Modelowanie i symulacja złóż ropy naftowej i gazu ziemnego. Pol. Geol. Rev. 1997, 45, 376-387.

65. Borys, Z. Aktualne problemy poszukiwań węglowodorów we wschodniej części przedgórza Karpat. Pol. Geol. Rev. 1996, 44, 1019-1023.

66. Uliasz-Misiak, B.; Chruszcz-Lipska, K. Hydrogeochemical aspects associated with the mixing of formation waters injected into the hydrocarbon reservoir. Miner. Resour. Manag. 2017, 33, 69-80. [CrossRef]

67. Ney, R.; Burzewski, W.; Bachleda, T.; Górecki, W.; Jakóbczak, K.; Słupczyński, K. Zarys paleogeografii i rozwoju litologicznofacjalnego utworów miocenu zapadliska przedkarpackiego. Pol. Geol. Rev. 1974, 82, 1-65.

68. Oszczypko, N. Przebieg mioceńskiej subsydencji w polskiej części zapadliska przedkarpackiego. Pr. Państw. Inst. Geol. 1999, 168, 209-230.

69. Garecka, M.; Jugowiec, M. Wyniki badań biostratygraficznych miocenu zapadliska przedkarpackiego na podstawie nanoplanktonu wapiennego. Pr. Państw. Inst. Geol. 1999, 168, 29-40.

70. Krzywiec, P. Geodynamic and tectonic control on evolution of foreland basins, with references to the Carpathian Foredeep Basin. Pol. Geol. Rev. 2006, 54, 404-412.

71. Jawor, E. The structure of the deep substratum in the region east of Cracow. Acta Geol. Pol. 1970, 20, 709-762.

72. Konior, K. General paleostructural analysis and characteristics of reservoir rocks of the Rzeszotary elevation and the neighbouring areas. Pol. Geol. Rev. 1978, 112, 3-63.

73. Plewa, M. The heat flow on the Polish territory. Zesz. Nauk. AGH Geofiz. Stosow. 1991, 1373, 141-151.

74. Gordienko, V.; Zavgorodnaya, O.V. Estimation of Heat Flow in Poland. Acta Geophys. Pol. 1966, 54, $173-180$.

75. Majorowicz, J.; Plewa, S. The results of surface heat flow investigations of the earth performed in Poland. Inst. Geophys. Acad. Sci. 1977, A-3, 103.

76. Karwasiecka, M.; Bruszewska, B. Gęstość powierzchniowego strumienia cieplnego na obszarze Polski. CAG 1997, 060, 21/98a.

77. Szewczyk, J.; Gientka, D. Terrestrial heat flow density in Poland-A new approach. Geol. Quart. 2009, 53, 125-140.

78. Sokołowski, J. Applicability of geothermal energy in Podkarpackie Voivodeship. Geol. Explor. Technol. Geotherm. Energy Sustain. Dev. 2002, 41, 9-19.

79. Sokołowski, J. Geological-structural characteristic and conditions of geothermal waters occurrence in Małopolskie Voivodeship. Geol. Explor. Technol. Geotherm. Energy Sustain. Dev. 2002, 41, 3-8.

80. Internet System of Legal Acts. The Geological and Mining Law (Journal of Laws 2020 Item 1064 Art. 5.1 point 2). Available online: http:/ /isap.sejm.gov.pl/isap.nsf/download.xsp/WDU20111630981/U/D20110981Lj.pdf (accessed on 7 July 2020).

81. Macioszczyk, A.; Dobrzyński, D. Hydrogeochemia strefy aktywnej wymiany wód podziemnych; PWN: Warszawa, Poland, $2002 ;$ p. 448.

82. Kotarba, M.J. Origin of natural gases in the autochthonous Miocene strata of the Polish Carpathian Foredeep. Ann. Soc. Geol Pol. 2011, 81, 409-424.

83. Poprawa, P.; Papiernik, B.; Krzywiec, P.; Machowski, G.; Maksym, A. Exploration potential of the Polish petroleum provinces. Wiadomości Naft. i Gazow. 2018, 12, 4-12.

84. Czernicki, J.; Kuk, S. Odkrycie złoża gazu ziemnego w utworach badenu dolnego w zapadlisku przedkarpackim. Nafta 1988, 3 , 41-46.

85. Kubica, B. Rozwój facjalny osadów chemicznych badenu w północnej części zapadliska przedkarpackiego. Pr. Państw. Inst. Geol. 1992, 133, 1-64.

86. Maksym, A.; Dziadzio, P.; Liszka, B.; Staryszak, G. Środowisko sedymentacji utworów miocenu autochtonicznego w brzeżnej strefie Karpat, a interpretacja geologiczno-złożowa w obszarze Husów-Albigowa-Krasne. Naft. Gaz 1997, 9, $407-414$.

87. Karnkowski, P. Poszukiwanie i rozpoznawanie złóż węglowodorów w nieantyklinalnych strukturach. Nafta 1983, 7-8, 219-226. 
88. Kotarba, M.J. Warunki generowania i akumulacji węglowodorów oraz charakterystyka geochemiczna substancji organicznej w utworach miocenu autochtonicznego zapadliska przedkarpackiego. Pr. Państw. Inst. Geol. 1999, 168, $277-295$.

89. Karnkowski, P. Oil and Gas Deposits in Poland; The Geosynoptics Society (GEOS): Kraków, Poland, 1999; pp. 1-379.

90. Myśliwiec, M. The presence of the normal faults and their relationships to gas accumulation, the Polish Carpathian Foredeep. In Proceedings of the 58th EAGE Conference and Technical Exhibition, Amsterdam, The Netherlands, 3-7 June 1996; Volume 2.

91. Tissot, B.; Mattavelli, L.; Brosse, E. Trends in Organic Geochemistry and Petroleum in Italy. Deposition of Organic Facies. AAPG Stud. Geol. 1990, 30, 161-179.

92. Lindal, B. Industrial and other applications of geothermal energy. Geothermal energy. In Earth Science, 12; Armstead, H.C.H., Ed.; UNESCO: Paris, France, 1973; p. 135.

93. Jawor, E. Poszukiwanie i rozpoznawanie złóż węglowodorów w niestrukturalnych pułapkach w środkowej części zapadliska przedkarpackiego. Nafta 1983, 39, 161-166.

94. Bulletin of Public Information of the Roźwienica Commune. Project's Characteristic. Available online: http:/ /www.rozwienica. itl.pl/bip/atach/4/1380/6261/Zal_cznik\%20do\%20decyzji_Charakterystyka\%20\%20przedsiewziecia\%20WOOS.420.13.5.2018. PW.75.pdf (accessed on 17 June 2020).

95. Tomaszewska, B.; Szczepański, A. Possibilities for the efficient utilisation of spent geothermal waters. Environ. Sci. Pollut. Res. 2014, 21, 11409-11417. [CrossRef] [PubMed]

96. Tester, J.W. Chapter 8-Environmental Impacts, Attributes, and Feasibility Criteria. In The Future of Geothermal Energy; Massachusettes Institute of Technology: Cambridge, MA, USA, 2006; pp. 1-19.

97. Nardini, I. 2013: Environmental Issues: An Overview of Possible Environmental Impacts Related to Geothermal Power Production. Available online: http:/ /www.geoelec.eu/wp-content/uploads/2013/07/GEOELEC-Environmental-issues_Nardini.pdf (accessed on 17 May 2021).

98. Allis, R.; Bromley, C.; Currie, S. Update on subsidence at the Wairakei-Tauhara geothermal system, New Zealand. Geothermics 2009, 38, 169-180. [CrossRef]

99. National Bank of Poland. Exchange Rates. Available online: https://www.nbp.pl/home.aspx?f=/kursy/kursya.html (accessed on 15 June 2020). 